DOI 10.15290/cnisk.2021.02.11.04

\author{
JOLANTA CHWASTYK-KOWALCZYK \\ https://orcid.org/0000-0002-3463-6432 \\ Uniwersytet Jana Kochanowskiego w Kielcach
}

\title{
Regina Wasiak-Taylor - animatorka kultury, dziennikarka, prezes Związku Pisarzy Polskich na Obczyźnie w Londynie ${ }^{1}$
}

\section{Streszczenie}

Celem artykułu jest zaprezentowanie Reginy Wasiak-Taylor - postaci wielu talentów, jako dziennikarki, sprawnej animatorki życia kulturalnego polskiej diaspory w Wielkiej Brytanii, prezes Związu Pisarzy Polskich na Obczyźnie (dalej: ZPPnO). Wykorzystano następujące metody: jakościową analizę zawartości prasy, krytyczną analizę dokumentów, analizę heurystyczna, wywiady. Poznajemy zakres działalności bohaterki: zaangażowanie w życie organizacyjne $\mathrm{ZPPnO}$, w redagowanie „Pamiętnika Literackiego" edytowanego w Londynie, uprawianie publicystyki społeczno-kulturalnej i krytyki literackiej, pisanie artykułów naukowych, popularyzację życia literackiego emigracji i polskiego baletu, organizowanie m.in. multimedialnych programów teatralnych i estradowych - Scena Poetycka przy Polskim Ośrodku Społeczno-Kulturalnym w Londynie (dalej: POSK). Także: zainicjowanie Salonu Literackiego w Ognisku Polskim na Exhibition Road, skierowanego do polskiej i międzynarodowej inteligencji w Londynie, czynny udział międzynarodowych konferencjach naukowych.

\footnotetext{
Publikacja przygotowana/finansowana w ramach programu Ministra Nauki i Szkolnictwa Wyższego pod nazwą DIALOG w latach 2019-2021. Jest wynikiem udziału w projekcie badawczym pt. „Ośrodek badań historii kobiet”, nr 0016/DLG/2019/10.
} 
Regina Wasiak-Taylor prowadzi prace redaktorskie przy edycji publikacji zwartych. Jest autorka odczytów, laudacji oraz własnych publikacji: Dzieje Nagrody Literackiej ZPPnO 1951-2011 (Londyn 2011), Ojczyzna literatura (Londyn 2013), Alfabet wspomnień Szymona Zaremby. II Rzeczpospolita, II wojna światowa, emigracja, (Londyn 2015). Inicjuje i prowadzi promocje książek polskich autorów oraz moderuje inne spotkania życia literackiego i naukowego w Ambasadzie RP w Londynie, na Międzynarodowych Targach Książki w Warszawie oraz na imprezach literackich w różnych miejscach.

Słowa kluczowe: Regina Wasiak-Taylor, Wielka Brytania, Londyn, 1980-2021, Zwiazek Pisarzy Polskich na Obczyźnie, londyński „Pamiętnik Literacki” 1976-2021

\title{
REGINA WASIAK-TAYLOR - CULTURE ANIMATOR, JOURNALIST, PRESIDENT OF THE ASSOCIATION OF POLISH WRITERS ABROAD IN LONDON
}

\begin{abstract}
The aim of the article is to present Regina Wasiak-Taylor - a person of many talents, as a journalist, an efficient animator of the cultural life of the Polish diaspora in Great Britain, a president of the Union of Polish Writers Abroad [hereinafter: ZPPnO - Zwiazek Pisarzy Polskich na Obczyźnie]. The following methods have been used: qualitative analysis of the press content, critical analysis of documents, heuristic analysis, interviews. We get to know Mrs Wasiak-Taylor's scope of activity: involvement in the organisational life of the ZPPnO, in the Pamiętnik Literacki [Literary Memoir] edited in London, practicing socio-cultural journalism and literary criticism, writing scientific articles, popularisation of the emigration's literary life and Polish ballet, organizing, among others, multimedia theatre and stage programmes - Poetic Scene [Scena Poetycka] at the Polish Social and Cultural Association [POSK - Polski Ośrodek Społeczno-Kulturalny] in London. Also: initiation of the Literary Parlour within the Polish Watchfire at the Exhibition Road, addressed to the Polish and international intelligentsia in London, active participation in international scientific conferences. Regina Wasiak-Taylor conducts editorial work on books. She is the author of readings, laudations, and her own publications: Dzieje Nagrody Literackiej ZPPnO 1951-2011 [The History of the Literary Award of the ZPPnO 1951-2011] (London 2011), Ojczyzna literatura [Literature Fatherland] (London 2013), Alfabet wspomnień Szymona Zaremby. II Rzeczpospolita, II wojna światowa, emigracja [Szymon
\end{abstract}


Zaremba's Alphabet of Memories, Second Polish Republic, World War II, emigration] (London 2015). She initiates and promotes books by Polish authors and moderates other meetings of literary and scientific circles at the Polish Embassy in London, at the International Book Fair in Warsaw and at literary events in various places.

Keywords: Regina Wasiak-Taylor, Great Britain, London, 19802021, Union of Polish Writers Abroad, London's Pamiętnik Literacki [Literary Memoir] 1976-2021

Wielka kreatorka polskiej kultury na Wyspach Brytyjskich oraz w Polsce jest dziennikarka, pisarka, współtwórczyni życia literackiego, obecna prezes Związku Pisarzy Polskich na Obczyźnie (dalej: ZPPnO), od dziesięcioleci „całkowicie zanurzona w żywiole tzw. polskiego Londynu"2 Regina Wasiak-Taylor. Urodziła się 28 kwietnia 1952 r. w Karczynie na Dolnym Śląsku. Ukończyła Technikum Geodezyjne we Wrocławiu w 1972 r. Przez dwa lata pracowała w Biurze Urbanistyki i Architektury w Krapkowicach. W 1974 rozpoczęła studia w Wyższej Szkole Pedagogicznej w Opolu na Wydziale Filologii Polskiej, zakończone magisterium w 1978 r. W okresie czteroletnich studiów brała udział w tworzeniu życia kulturalnego społeczności akademickiej, prowadząc Koło Naukowe Polonistów WSP.

W 1977 r. podjęła pracę w Redakcji Literackiej Polskiego Radia w Opolu, przygotowujac reportaże i programy literackie, zainicjowała stały program niedzielny poświęcony kulturze i jej twórcom na Opolszczyźnie. Pod koniec listopada 1981 r. wyjechała na urlop do Londynu, gdzie zastało ją ogłoszenie stanu wojennego w Polsce i na fali „solidarnościowej” emigracji uzyskała status obywatelski w Wielkiej Brytanii. W połowie lat 80. XX w. została stałym korespondentem dziennika „Kurier Polski” (do 1990 r.) w Wielkiej Brytanii.

$\mathrm{Z}$ pełnym zaangażowaniem włączyła się w życie organizacyjne istniejącego od 1946 r. Związku Pisarzy Polskich na Obczyźnie (dalej: ZPPnO) w Londynie, w którego poczet została przyjęta w 1983 r. W kolejnym weszła do Zarzadu tej organizacji oraz do redakcji jej organu - „Pamiętnika Literackiego”3. Początkowo była

\footnotetext{
2 Słowa prof. Beaty Dorosz, „Zapomniani pisarze emigracyjni”, Pamiętnik Literacki (dalej: $P L)$, t. 57, 2019, 36.

3 Szerzej o „Pamiętniku Literackim” zob. Jolanta Chwastyk-Kowalczyk, Londyński „Pamiętnik Literacki" - organ Zwiąku Pisarzy Polskich na Obczyźnie - w latach 1976-2018, (Kielce: Wydawnictwo Uniwersytetu Jana Kochanowskiego, 2019); „Kronika Zwiąku”, PL, t. 10, 1986, 103.
} 
członkiem kolegium redakcyjnego, następnie długoletnim sekretarzem redakcji ${ }^{4}$. Funkcję tę sprawowała przez 34 lata aż do grudniowego tomu LIV z 2017 r., kiedy została wybrana na walnym zgromadzeniu w 2017 r. prezesem ZPPnO, obejmując zwyczajowo jednocześnie funkcję redaktora naczelnego pisma Związku. Odtąd to ona pisze "Słowo wstępne” czy "Od Redakcji” do każdego tomu półrocznika, jakim jest „Pamiętnik Literacki” od 2006 r. Choć wcześniej także się zdarzało ${ }^{5}$. Regularnie opracowywała „Kronikę Związku”, pomieszczaną w każdym numerze „Pamiętnika Literackiego”.

Wraz z mężem Martinem Taylorem od wielu lat zasilaja prywatnymi środkami konto Funduszu Prasowego „Pamiętnika Literackiego" założonego przez ZPPnO ${ }^{6}$. Józef Garliński, odchodząc $z$ redakcji pisma, nie mógł przypuszczać, że od kilku dekad to jej imponujaca determinacja jest gwarantem istnienia periodyku oraz kontynuacji idei Kazimierza Sowińskiego i jego, przyświecającej powołaniu go do życia. $Z$ wielkim trudem uzyskuje fundusze na ten cel, nie mając stałego źródła finansowania tego przedsięwzięcia, puka do wielu drzwi, pisze niezliczona ilość listów z prośbą o wsparcie, nieustająco próbuje przekonać spotkanych ludzi, że to ważne, że należy, że istnieją czytelnicy, którzy czekają na ukazanie się kolejnego tomu. Należy przyznać, że Regina Wasiak-Taylor ma zdumiewajaca i rzadka umiejętność wyzwalania dobrej energii i aktywizowania ponad podziałami wszelkiej proweniencji innych, by uczestniczyli w tworzeniu życia intelektualno-artystycznego na obczyźnie. „Pamiętnik" jest efektem zbiorowej twórczej pulsacji i dowodem na potrzebę duchowej strawy niszowego wykształconego odbiorcy.

Zapytana, jakim słowem określa swoja działalność w środowisku polonijnym, powiedziała: „Najbardziej odpowiada mi określenie Tymona Terleckiego, który pisząc wspomnienie o Ostapie Ortwinie powiedział, że był on typem działacza literackiego, który ponad pisanie przedkładał działanie, jakąś kulturalną odmianę tego, co Sorel w swojej teorii społecznej nazywał "action directe»"7.

$P L$, t. 8, 1984, stopka redakcyjna.

Np. PL, t. 35, 2008, 7; PL, t. 38, 2009, 7.

6 Zob. np.: „Wyniki apelu na Fundusz Prasowy "Pamiętnika Literackiego" ogłoszony przez Zarząd Związku Pisarzy Polskich na Obczyźnie”, PL, t. 27, 2002, 117; „Wpłaty na Fundusz Prasowy "Pamiętnika Literackiego" oraz Związek Pisarzy Polskich na Obczyźnie”, PL, t. 57, 2019, 4.

7 E-mail Reginy Wasiak-Taylor do Jolanty Chwastyk-Kowalczyk, 29.01.2020, archiwum Jolanty Chwastyk-Kowalczyk. 
Od 2008 r. współpracowała z zespołem teatralnym Scena Poetycka przy POSK-u w Londynie jako kierownik literacki (do 2013 r. ${ }^{8}$ ), a także Teatru Baletowego prowadzonego przez Svetlanę Gaidę Cracow Centre Ballet. Jest członkiem Krakowskiej Fundacji Kultury Baletowej. Kilkakrotnie zaprosiła młodzież krakowską i kilku znanych tancerzy baletowych $z$ Europy na występy artystyczne dla publiczności polonijnej i brytyjskiej (2008-2013).

Prace pisarskie, działania popularyzujące kulturę literacka emigracji i polska sztukę baletową łączy $z$ powodzeniem, organizujac m.in. multimedialne programy teatralne i estradowe. Takich programów i spotkań literackich przygotowała w Wielkiej Brytanii ok. 400. Przykładowo 20 marca 2012 r. w Jazz Café w POSK-u odbył się spektakl anglojęzycznej sztuki Marii Jastrzębskiej pt. Dementia, w 10-osobowej obsadzie autorskiej i muzycznej. Tłumnie przybyła publiczność powitała w imieniu ZPPnO Regina Wasiak-Taylor, która omówiła sylwetkę twórczą autorki ${ }^{9}$. W 2012 r. wymyśliła wspólnie $z$ aktorem, reżyserem, scenarzystą Januszem Guttnerem comiesięczne „Czytania utworów wybitnych polskich poetów" ${ }^{10}$. Odbywają się w Ognisku Polskim w Londynie w niedzielę (ruchoma) do dzisiaj. Zaczęto od Wisławy Szymborskiej, w tydzień po jej śmierci. Pomysł został znakomicie przyjęty przez publiczność i zyskał stałych odbiorców i uczestników. Spotkania obejmuja część artystyczna - recytacje, czytania, czasem muzykę i śpiewana poezję oraz wprowadzenie do twórczości prezentowanego poety oraz dyskusję.

Pomysłem Reginy Wasiak-Taylor, o którym miałyśmy okazję niejednokrotnie rozmawiać podczas wielu pobytów autorki tego opracowania w Londynie, jest zainicjowanie Salonu Literackiego w Ognisku Polskim na Exhibition Road, skierowanego do polskiej i międzynarodowej inteligencji w Londynie. Jego otwarcie nastapiło 2 grudnia 2012 r. Do dzisiaj cieszy się wielkim powodzeniem. Stanowi poważna polsko-angielska ofertę kulturalna ZPPnO. Regina Wasiak-Taylor jest gospodynią Salonu. $Z$ każdego spotkania ukazują się sprawozdania różnych autorów w Pamiętniku Literackim ${ }^{11}$.

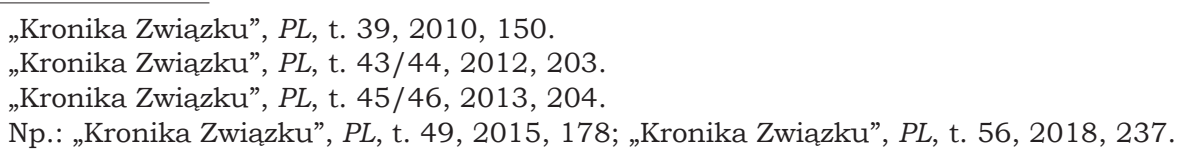


Sama Regina Wasiak-Taylor zabrała głos na temat Salonu Literackiego ZPPnO, pisząc reportaż do „Pamiętnika Literackiego", zainspirowana występem Magdaleny Zawadzkiej w Londynie w 2016 r. ${ }^{12} \mathrm{Na}$ tę stała imprezę zwyczajowo zaprasza się znanego pisarza lub sławnego gościa z książka, jak bowiem stwierdziła Regina Wasiak-Taylor: „Ksiażka jest medium naszych spotkań, ale czasem bywa tylko pretekstem lub nawiązaniem"13. Opisała także inne Salony ${ }^{14}$.

Regina Wasiak-Taylor od 2008 r. promuje Zwiazek Pisarzy Polskich na Obczyźnie na Warszawskich Targach Książki.

W 2017 r. rozpoczęła organizację corocznych konferencji i sesji naukowych poświęconych zapomnianym pisarzom emigracyjnym. Biora w nich udział uczeni i badacze $z$ Polski oraz członkowie ZPPnO $z$ całego świata ${ }^{15}$. Pierwszą edycję konferencji o zapomnianych pisarzach emigracyjnych poprzedziła sesja popularnonaukowa (urzadzona również na 8. Warszawskich Targach Książki) popularyzująca cztery dekady istnienia londyńskiego „Pamiętnika Literackiego”. Na dwie następne konferencje zaproszono do Klubu Księgarza w Warszawie, a następnie do Klubu Dziennikarza „Pod Gruszką” w Krakowie. Z okazji 70-lecia powstania ZPPnO oraz benefisu Andrzeja Krzeczunowicza przygotowała program artystyczno-literacki pod patronatem Prezydenta RP i Ministerstwa Kultury i Dziedzictwa Narodowego w Teatrze Stanisławowskim w warszawskich Łazienkach. Trzydziestoosobowej grupie artystów i pisarzy przybyłych znad Tamizy towarzyszyła Orkiestra im. Szymanowskiego pod dyr. prof. Szymona Kawalli i kilkoro krajowych artystów i twórców.

Wasiak-Taylor wygłaszała referaty na kilku konferencjach naukowych organizowanych przez ośrodki akademickie i inne w kraju. Tak przedstawia się chronologicznie jej udział w konferencjach naukowych:

- 18-19 X 2012, Poznań, Międzynarodowa Konferencja Naukowa pod hasłem: „Wybitni działacze wychodźstwa polskiego na emigracji w XIX i XX wieku”. Uniwersytet

\footnotetext{
12 Regina Wasiak-Taylor, „Szekspir, Maria i Magdalena”, PL, t. 52, 2016, 59-68.

13 Ibidem, 59.

14 Regina Wasiak-Taylor, „Siostra Bożena i sor Juana Inés de la Cruz”, PL, t. 53, 2017, 115-124; eadem, „Podleska w 17. Salonie Literackim”, PL, t. 54, 2017, 209-219; „Kronika Zwiąku”, PL, t. 52, 2016, 221.

15 Zob. rozdział 4. „Życie literackie w optyce pisma”, w: Jolanta Chwastyk-Kowalczyk, Londyński „Pamiętnik Literacki”, 153-204.
} 
im. Adama Mickiewicza, Instytut Wschodni Wydziału Historycznego; temat referatu: Krystyna i Czesław Bednarczykowie - wydawcy, poeci, drukarze.

- 9 kwietnia 2016, Polski Uniwersytet na Obczyźnie (dalej: PUNO), Londyn POSK - VI kwietniowa konferencja PUNO pod hasłem: „Wkład polskich artystów i pisarzy w kulturę brytyjska po roku 1945”. Temat referatu: Krytyka literacka $i$ artystyczna Zdzisława Broncla $w$ świetle materiałów prasowych. Ukazał się w: The Hanna and $Z d-$ zisław Broncel Charitable Trust, London: PUNO PRESS, 2016, 63-82.

- 8. Warszawskie Targi Książki, Warszawa, 13 maja 2017, sala Londyn na Stadionie X-lecia - konferencja $z$ okazji 40-lecia założenia „Pamiętnika Literackiego”. Temat referatu: Kazimierz Sowiński - inicjator powstania pisma literackiego na obczyźnie. Tekst ten ukazał się w londyńskich „Zeszytach Naukowych PUNO” w 2016 r. ${ }^{16}$

- 8. Warszawskie Targi Książki, Warszawa, 14 maja 2017, sala na Stadionie X-lecia - konferencja „Zapomniani pisarze emigracyjni", I edycja. Temat referatu: Wit Tarnawski $i$ Conrad. Tekst ten ukazał się w „Pamiętniku Literackim” w 2018 r. ${ }^{17}$

- 9. Warszawskie Targi Książki, Warszawa, 19 maja 2018, Klub Księgarza - Konferencja „Zapomniani pisarze emigracyjni”. II edycja. Temat referatu: Od wierszy serdecznych Bolesława Kobrzyńskiego po haiku. Tekst ten ukazał się w „Pamiętniku Literackim” w 2019 r. ${ }^{18}$

- 16 lutego 2019, Londyn, POSK - Międzynarodowa konferencja naukowa w 50. rocznicę śmierci Poety „Życie i twórczość Kazimierza Wierzyńskiego (1894-1969)". 16 naukowców, wykładowców związanych z kilkoma uczelniami na świecie wzięło w niej udział. Temat referatu: Zwiazek Pisarzy Polskich na Obczyźnie i Kazimierz

\footnotetext{
16 Regina Wasiak-Taylor, „Kazimierz Sowiński - pisarz, inicjator pisma Zwiąku Pisarzy Polskich na Obczyźnie", Zeszyty Naukowe PUNO. Seria trzecia, nr 4, 2016, 183-194.

17 Regina Wasiak-Taylor, „Wit Tarnawski i Conrad”, PL, t. 55, 2018, 71-78.

18 Regina Wasiak-Taylor, „Od poezji serdecznych po haiku Bolesława Kobrzyńskiego”, PL, t. 57, 2019, 93-105.
} 
Wierzyński. Tekst jest $\mathrm{w}$ opracowaniu redakcyjnym i ukaże się w wieloautorskiej monografii w 2021 r.

- 20 marca 2019, Warszawa, Akademia Pedagogiki Specjalnej im. Marii Grzegorzewskiej, sympozjum „Literatura emigracyjna wczoraj i dziś". Temat referatu: Środowisko literackie skupione wokół Zwiąku Pisarzy Polskich na Obczyźnie.

- 10. Warszawskie Targi Ksiażki, Warszawa, 23-26 maja 2019. Regina Wasiak-Taylor jako prezes ZPPnO i gospodarz stoiska 351/G ZPPnO udzieliła wielu wywiadów dla różnych stacji telewizyjnych i prasy. Tym razem sesję naukowa zorganizowano w Krakowie 30 maja 2019 r. w Klubie Dziennikarzy „Pod Gruszka”. Podczas koncertu „Przede wszystkim Moniuszko" na deskach teatru w POSK-u Regina Wasiak-Taylor podawała w anegdocie informacje dotyczące ZPPnO przy akompaniamencie muzyki Stanisława Moniuszki.

- Wręczenie Nagrody Literackiej ZPPnO za 2018 rok odbyło się w Domu Polonii na Krakowskim Przedmieściu 25 maja 2019 r. - spotkanie poprowadziła Regina Wasiak-Taylor ${ }^{19}$.

- 9-11 kwietnia 2021, Londyn, Polski Uniwersytet na Obczyźnie, międzykontynentalna konferencja naukowa pn. „Cyprian Norwid Yesterday and Today". Temat referatu: Prekursorskie wydawnictwa $w$ Anglii.

Była jedna z osób, które przygotowały w 2017 r. I edycję Świątecznego Festiwalu Literatury dla Dzieci, odbywającego się 8 grudnia w Muzeum im. gen. Władysława Sikorskiego w Londynie $z$ udziałem autorek i ilustratorek książek dla dzieci $z$ Wielkiej Brytanii ${ }^{20}$.

Uprawia publicystykę społeczno-kulturalną i krytykę literacka. Swoje teksty drukowała w londyńskich periodykach emigracyjnych, takich jak: „Dziennik Polski i Dziennik Żołnierza” ${ }^{21}$ oraz

\footnotetext{
19 Grażyna Maxwell, „Związek Pisarzy w delegacji”, PL, t. 57, 2019, 283-286; „Kronika Związu", PL, t. 57, 2019, 279.

20 „Kronika Związku”, PL, t. 56, 2018, 238.

21 Zob. monografie: Jolanta Chwastyk-Kowalczyk, Londyński „Dziennik Polski” 1940-1943, (Kielce: Wydawnictwo Akademii Świętokrzyskiej, 2005); eadem, Londyński „Dziennik Polski i Dziennik Żolnierza” 1944-1989. Gazeta codzienna jako środek przekazu komunikatów kulturowych, (Kielce: Wydawnictwo Uniwersytetu Humanistyczno-Przyrodniczego Jana Kochanowskiego, 2008).
} 
w jego sobotnim dodatku społeczno-kulturalnym „Tydzień Polski”22, „Orzeł Biały”, „Gazeta Niedzielna”, „Zeszyty Naukowe PUNO”, także w paryskiej „Kulturze”, jak również w krajowych - miesięczniku „Opole” i wrocławskiej „Odrze”23.

Profesor Beata Dorosz słusznie zauważyła, że dla Reginy Wasiak-Taylor:

To, co my badacze $z$ kraju, znamy $z$ literatury i pieczołowicie odkrywamy podczas kwerend archiwalnych, jest jej codziennościa, bo miała szczęście znać swoich bohaterów: Władę Majewska, Krystynę i Czesława Bednarczyków, Szymona Zarembę oraz wielu innych znanych i lubianych, ale też zapomnianych lub żyjących w cieniu emigrantów. Jej emigracyjną codziennością są także udręki, przypisane do ... funkcjonowania ZPPnO. Parafrazując jej własne słowa o nagrodach literackich Zwiazku (,zaszczyt wielki, korzyść mniejsza"24) można określić wybranie jej na prezesa Związku słowami „zaszczyt wielki, harówka jeszcze większa”, a osobę podejmującą takie działania musi cechować przede wszystkim determinacja ${ }^{25}$.

Jako dziennikarka w „Pamiętniku Literackim” zaistniała, przeprowadzajac w $1983 \mathrm{r}$. dwa wywiady z literatami nagrodzonymi przez ZPPnO - zamieszkałym w nadmorskiej miejscowości St. Leonards w Anglii poeta, prozaikiem, pamiętnikarzem, badaczem i wydawcą utworów Cypriana K. Norwida Zbigniewem Zaniewickim (nagroda za całokształt twórczości) oraz zamieszkała w Stanach Zjednoczonych polska poetka i pisarka, socjologiem i filozofem $\mathrm{dr}$ Alicją Iwańską (nagroda za najlepszą książkę 1982 r. Wojenne odcinki: Warszawa 1940-1943) ${ }^{26}$.

Przez dziesięciolecia przeprowadzi jeszcze wiele rozmów $z$ ludźmi pióra, uczonymi, politykami i innymi działaczami emigracyjnymi oraz wydawcami, które zostana opublikowane na łamach periodyku ZPPnO. W roku 1988 tomy XII i XIII „Pamiętnika Literackiego" miały być poświęcone bibliotekom polskim poza krajem.

\footnotetext{
22 W związku z likwidacja „Dziennika Polskiego i Dziennika Żołnierza” 15 lipca 2015 r. dotychczasowy samoistny dodatek „Tydzień Polski” usamodzielnił się i jest edytowany jako tygodnik w Londynie do dzisiaj.

23 Informacje pochodzące od Reginy Wasiak-Taylor; także e-mail Reginy Wasiak-Taylor do Jolanty Chwastyk-Kowalczyk, 5.01.2020, archiwum Jolanty Chwastyk-Kowalczyk.

24 Regina Wasiak-Taylor, „Zaszczyt wielki, korzyść mniejsza”, PL, t. 42, 2011, 19.

25 Beata Dorosz, „Zapomniani pisarze emigracyjni”, PL, t. 57, 2019, 36.

26 Regina Wasiak, „Nasi laureaci”, PL, t. 7, 1983, 79-91.
} 
Dwa lata wcześniej, chcac przybliżyć funkcjonowanie Biblioteki Polskiej w Londynie, Regina Wasiak spotkała się z dr. Zdzisławem Jagodzińskim, kierownikiem tej placówki, powstałej w 1942 r. ${ }^{27}$ Zainspirowana tą rozmową napisała, opierając się na źródłach archiwalnych, artykuł o znaczeniu polskiej książnicy wprost proporcjonalnym do osobistych zasług jej szefów - Marii Danilewicz-Zielińskiej i Zdzisława Jagodzińskiego ${ }^{28}$.

Rozmowa $z$ Magdalena Abe ukazała czytelnikom pisma działalność i osiagnnięcia pierwszego polskiego wydawnictwa w kraju poza cenzura, tzw. drugiego obiegu, w zakresie publikowania literatury emigracyjnej - Niezależnej Oficyny Wydawniczej NOWA, funkcjonujacej w Warszawie w latach 1977-198929.

Bardzo ciekawe aspekty 24 lat pracy nad „Pamiętnikiem Literackim", jego specyfiką i historia powstania, wyłoniły się $z$ wywiadu, jaki w 1999 r. przeprowadziła Regina Wasiak-Taylor z redaktorem, wydawcą i prezesem ZPPnO dr. Józefem Garlińskim, którego znała wtedy od czternastu lat i którego uważała za „tytana pracy i najpłodniejszego pisarza emigracyjnego" ${ }^{30}$. Refleksje Garlińskiego były jednocześnie pożegnaniem $z$ czytelnikami periodyku, ze względu bowiem na zaawansowany wiek i zły stan zdrowia przekazał redakcje pisma oraz ster ZPPnO w inne ręce ${ }^{31}$. Jednak do ostatecznego rozstania Garlińskiego $z$ redakcja pisma doszło dopiero w roku $2003^{32}$. Wtedy na krótko (bowiem zmarł w 2004 r.) nowym prezesem ZPPnO został prof. Mieczysław Paszkiewicz. Regina Wasiak-Taylor z okazji wieczoru poezji Paszkiewicza, historyka sztuki, pedagoga, wykładowcy i wieloletniego dziekana Wydziału Humanistycznego PUNO, omówiła na łamach „Pamiętnika Literackiego” jego wojenne losy, niewolę w Oświęcimiu, edukację w 2 Korpusie, studia w Regent Polytechnic School of Art, pracę zawodowa jako grafika w angielskiej firmie reklamowej, założenie wraz z Ludwikiem Angererem miesięcznika „Merkuriusz Polski” w Londynie, współpracę z „Kon-

\footnotetext{
27 „Biblioteki polskie poza krajem”, $P L$, t. 10, 1986, 55-58.

28 Regina Wasiak, „Biblioteka Polska w Londynie”, PL, t. 12, 1988, 66-81.

29 Regina Wasiak, „Literatura emigracyjna w drugim obiegu. Wywiad z Magdaleną Abe, $P L$, t. 13, 1988, 66-72; szerzej o samym wydawnictwie: Łukasz Bertram (wybór i oprac.), Obieg NOW-ej, (Warszawa: Ośrodek Karta i IPN, 2013); Małgorzata Choma-Jusińska, Środowiska opozycyjne na Lubelszczyźnie. 1975-1980, (Lublin: IPN, 2009).

30 Regina Wasiak-Taylor, „24 lata w roli redaktora i wydawcy”, PL, t. 24, 1999, 103-109.

31 Józef Garliński, „Czy pożegnanie?”, PL, t. 24, 1999, 110.

32 Józef Garliński, „Pożegnanie”, PL, t. 28, 2003, 7.
} 
tynentami" oraz dorobek naukowy i poetycki ${ }^{33}$. Wieczór, urządzony przez ZPPnO wraz z PUNO w Londynie, odbył się 22 maja 2003 r. w Sali Orłów w Polskim Ośrodku Społeczno-Kulturalnym.

Temat wolności słowa i likwidacji cenzury prewencyjnej w kraju po wyborach w czerwcu 1989 r. wybrzmiał w rozmowie z publicysta, krytykiem i historykiem literatury, działaczem opozycji demokratycznej w okresie PRL, współzałożycielem Komitetu Obrony Robotników i Komitetu Samoobrony Społecznej „KOR”, członkiem zarządu Regionu NSZZ „Solidarność” Mazowsze Janem Józefem Lipskim ${ }^{34}$.

Dwa wywiady przeprowadziła $z$ młodymi Angielkami, absolwentkami studiów polonistycznych na London School of Slavonic and East European Studies - Rosemary Hunt i Niną Taylor ${ }^{35}$ (późniejszą żoną dr. Tymona Terleckiego), które stały się wielkimi admiratorkami polskiej kultury i języka polskiego ${ }^{36}$.

Regina Wasiak-Taylor wyławia ze świata nauki badaczy, którzy zajmują się polską literaturą. O ten zakres zainteresowań zapytała Ursulę Phillips, zwiazana ze School of Slavonic and East European Studies na University College w Londynie ${ }^{37}$. Uczona, popularyzatorka polskiej kultury i tłumaczka, doktoryzowała się z historii literatury polskiej XIX w. Za przekład powieści Choucas Zofii Nałkowskiej otrzymała w 2015 r. nagrodę the Found in Translation Award. Na swoim koncie ma również wiele innych tłumaczeń, m.in. utwory powieściopisarki i poetki, uważanej za prekursorkę feminizmu w Polsce - Narcyzy Żmichowskiej, która szczególnie sobie upodobała. W 2019 r. przypadała dwusetna rocznica urodzin Żmichowskiej. Phillips dla jej uczczenia wystapiła w Londynie 20 lute-

\footnotetext{
33 Regina Wasiak-Taylor, „Wieczór poezji Mieczysława Paszkiewicza”, PL, t. 28, 2003, 111-115.

34 Regina Wasiak, „Polska na rozdrożu. (Autoryzowana rozmowa z Janem Józefem Lipskim)”, $P L$, t. 14, 1989, 138-141.

35 Nina Taylor - ur. 1942 r. w Londynie; w latach 1961-1964 studiowała rusycystykę na Uniwersytecie w Oxfordzie, a później w latach 1978-1981 - polonistykę na London School of Slavonic and East European Studies. Doktorat w latach 80. XX w. za pracę pt. Legenda litewska: Tadeusz Konwicki i polska tradycja krajobrazowa. Druga żona organizatora życia naukowego i literackiego w Anglii oraz Stanach Zjednoczonych dr. Tymona Terleckiego. Po jego śmierci (2000 r.) kustosz jego wielotorowej twórczości w dziedzinie krytyki literackiej i teatralnej oraz eseistyce. Ma wykłady na uniwersytetach brytyjskich; czynnie uczestniczy w międzynarodowych konferencjach naukowych, gdzie propaguje spuściznę męża. Za: $P L$, t. 9, 1985, 111; PL, t. 14, 1989, 155-156.

36 Regina Wasiak, „Polszczyzna jest moja obsesją, $P L$, t. 9, 1985, 101-106; eadem, „Nie ma ucieczki od Soplicowa”, PL, t. 9, 1985, 106-111.

37 Regina Wasiak-Taylor, „Narcyza and Ursula”, PL, t. 56, 2018, 101-106.
} 
go 2019 r. $z$ wykładem w ramach spotkania o kobietach pisarkach w literaturze polskiej od lat 40. XIX w.

W dziale „Nasi laureaci”, na przemian z Józefem Garlińskim i Józefem Bujnowskim, przybliżała postacie nagrodzonych przez ZPPnO twórców. W 1984 r. publikuje esej o uniwersalnej twórczości największego współczesnego dramaturga polskiego na emigracji Sławomira Mrożka, nagrodzonego za całokształt twórczości ${ }^{38}$. Zaprezentowała ponadto m.in.: emigracyjna pisarkę, tworzaca dla dzieci i młodzieży, uhonorowana nagroda literacka za całokształt twórczości w 1985 r. - Martę Reszczyńską-Stypińską ${ }^{39}$; współpracownika „Pamiętnika Literackiego” ze Szwecji dr. Andrzeja Nilsa Ugglę $e^{40}$; wieloletniego stałego współpracownika periodyku ze Stanów Zjednoczonych prof. Jerzego Ryszarda Krzyżanowskiego ${ }^{41}$.

Jury Nagrody Związku Pisarzy Polskich na Obczyźnie w 2007 r. przyznało laur za najlepszą książkę poprzedniego roku wydawniczego napisana przez pisarza emigracyjnego byłej asystentce Melchiora Wańkowicza, mieszkającej w USA Aleksandrze Ziółkowskiej-Boehm za utwór Kaja od Radosława, czyli historia Hubalowego krzyża. Jest to literacka opowieść reportażowa o losach Cezarii Iljicz-Kai, która autorka znała osobiście od 30 lat. Regina Wasiak-Taylor, zasiadajaca w gronie jury, wejrzała w dotychczasowy dorobek literacki pisarki, będącej znawczynią życia i dokonań epickich Melchiora Wańkowicza i zgodnie $z$ wola zmarłego w 1974 r. pisarza - opiekunka i spadkobierczynia jego archiwum ${ }^{42}$. Przeprowadziła $z$ nia także interesujący obszerny wywiad, w którym poruszono watki nieakceptowanej przez tzw. polski Londyn postawy moralnej pisarza (powrót do Polski w 1958 r.), upowszechnienie legendy o Monte Cassino i Hubalczykach, wpływu Wańkowicza na twórczość nagrodzonej, jej warsztatu reportażu literackiego, podejmowanych tematów w szkatułkowych opowieściach, „pełnych dygresji, wolnych od skrępowań konwencjonalnych struktur fabularnych, pękających

38 Regina Wasiak, „Nasi laureaci. Kilka myśli o Mrożku”, PL, t. 8, 1984, 110-114.

39 Regina Wasiak, „Nasi laureaci. Nie tylko dla dorosłych”, PL, t. 10, 1986, 70-74.

40 Regina Wasiak-Taylor, „Nasi laureaci: Ryszard Kazimierz Lewański, Andrzej Nils Uggla”, $P L$, t. 21, 1996, 104-106.

41 Regina Wasiak-Taylor, „Nasi laureaci: Jerzy R. Krzyżanowski, Ludwika Amber”, PL, t. 22, 1997, 80-81.

42 Regina Wasiak-Taylor, „Dwukrotny sukces Aleksandry Ziółkowskiej-Boehm - książka i nagroda", $P L$, t. 35, 2008, 65-66. 
od faktograficznego surowca"43. Regina Wasiak-Taylor na spotkaniu ZPPnO 9 grudnia 2008 r. w Jazz Café w POSK-u, gdzie wręczono Aleksandrze Ziółkowskiej-Boehm nagrodę, wygłosiła na jej cześć laudację ${ }^{44}$.

Temat książki na emigracji pojawił się w rozmowie przeprowadzonej w Londynie w 2010 r. z inżynierem wodno-lądowym i drogowym $z$ wykształcenia, a $z$ zamiłowania wydawca i księgarzem - Jerzym Kulczyckim, który w 1964 r. założył w stolicy Wielkiej Brytanii Wydawnictwo Odnowa, istniejące do roku $1990^{45}$. Kulczycki w 1972 r. kupił wraz z żoną Aleksandrą księgarnię Orbis Books w Londynie, która prowadził z nią do 2008 r. W czasach PRL był zaangażowany $\mathrm{w}$ wysyłkę książek emigracyjnych do Polski. Należy nadmienić, że w 2016 r. pośmiertnie wydano w Warszawie jego wspomnienia Atakować ksią̇ka ze wstępem Andrzeja Paluchowskiego, w opracowaniu Małgorzaty Chomy-Jusińskiej i Pawła Ziętary.

Regina Wasiak-Taylor jest autorką krytycznych artykułów na różne tematy opublikowanych głównie na łamach londyńskiego „Pamiętnika Literackiego”. Jednak literatura i życie literackie niezmiennie pozostaja w kręgu jej najbliższych zainteresowań. Już w 1984 r. swoje uwagi, sugestie i życzenia sformułowała w bardzo krytycznej analizie krajowych opracowań współczesnej literatury polskiej na obczyźnie ${ }^{46}$. Wyraziła opinię, że ,jedyna publikacja aktualnie gromadzaca materiał dokumentarny, literacko-bibliograficzny jest "Pamiętnik Literacki». ... Można dyskutować i poddawać krytyce obszar penetracji dokonywanej przez "Pamiętnik", ale nie można podważyć jego idei i rezygnować $z$ tego jedynego, aktualnego źródła wiedzy"47.

W tomie XI „Pamiętnika Literackiego” z 1987 r., poświęconym 40-leciu istnienia Instytutu Literackiego w Paryżu i jego zespołowi, zebrała głosy różnych osób o „Kulturze”48.

Za znakomita syntezę należy uznać jej artykuł na temat polskiej dramaturgii powstałej na obczyźnie po 1939 r. do końca XX w.,

\footnotetext{
43 Regina Wasiak-Taylor, „Na tropach Aleksandry Ziółkowskiej-Boehm”, PL, t. 35, 2008, 67-81.

44 „Kronika Zwiąku”, PL, t. 36, 2008, 156.

45 Regina Wasiak-Taylor, „Książka w herbie Jerzego Kulczyckiego”, PL, t. 40, 2010, 67-82.

46 Regina Wasiak, „Na marginesie krajowych opracowań literatury polskiej na obczyźnie”, $P L$, t. 8, 1984, 75-86.

47 Ibidem, 85.

48 Regina Wasiak, „Głosy o "Kulturze»”, PL, t. 11, 1987, 35-38.
} 
w którym wnikliwie, w oparciu o wiele wiarygodnych źródeł, opisała pisarzy emigracyjnych tworzacych dla scen Związku Artystów Scen Polskich za Granica, czyli Teatru Dramatycznego 2. Korpusu, Czołówki Lotniczej, Czołówki Teatralnej Wojska Polskiego, Czołówki I Brygady Strzelców, Polskiego Teatru Dramatycznego, Teatru Hemara, Teatru Ref-Rena, Teatru Sztuk Czytanych, Teatru „Pro-Arte"49. Ciekawym uzupełnieniem tej tematyki jest omówienie przez Reginę Wasiak-Taylor dorobku polskich przedstawicieli krytyki teatralnej w Wielkiej Brytanii ${ }^{50}$. Skupiła się na rozważaniach, sugestiach i przemyśleniach teoretyka teatru dr. Tymona Terleckiego, aktora i reżysera, publicysty Zygmunta Nowakowskiego, felietonisty radiowego i dziennikarza prasowego Zdzisława Broncla, poety, satyryka, komediopisarza, dramaturga, tłumacza poezji, autora tekstów piosenek Mariana Hemara, dr. filozofii, aktora, reżysera teatralnego, pisarza, dziennikarza i działacza emigracyjnego Leopolda Pobóg-Kielanowskiego, dziennikarzy i pisarzy Wacława Zagórskiego, Karola Zbyszewskiego, Juliusza Sakowskiego, poety Stanisława Balińskiego, recenzentów Tamary Karren, Macieja Cybulskiego, artysty Wiesława Mireckiego i innych. Wasiak-Taylor wyraziła opinię, że „Obecni recenzenci życia teatralnego w Londynie sa niewątpliwie odważniejsi w ocenie. Niestety jednak, jak do tej pory miejsca po krytykach-teatrologach i krytykach-literatach pozostały puste" ${ }^{51}$.

Regina Wasiak-Taylor przypomniała „Niezwykłą karierę "Czerwonych maków" - najsłynniejszej pieśni wojskowej autorstwa Feliksa Konarskiego (Ref-Rena) i Alfreda Schütza, która obrosła w legendę i do legendy przeniosła swoich autorów, historię jej powstania w noc majowa z 17 na 18 maja w 1944 r. pod Monte Cassino, pierwszego wykonania pod murami zdobytego klasztoru, wreszcie zdobycia popularności ${ }^{52}$.

Po śmierci w 2006 r. w Londynie literatki Ireny z Zabłockich Baczkowskiej, opisujacej w swoich utworach ziemie dawnej Rzeczypospolitej, północne rubieże Kresów Wschodnich, polskie ziemiaństwo, wojenna tułaczkę i powojenna emigrację, Regina Wasiak-

\footnotetext{
49 Regina Wasiak-Taylor, „Pisarze emigracyjni tworzacy dla scen ZASP-u za granica”, $P L$, t. 25, 2000, 50-72.

50 Regina Wasiak-Taylor, „O krytyce i krytykach teatru emigracyjnego w Londynie”, $P L$, t. 27, 2002, 63-80.

51 Ibidem, 78.

52 Regina Wasiak-Taylor, „Niezwykła kariera "Czerwonych maków»”, PL, t. 29, 2004, 89-93.
} 
-Taylor podjęła się trudu zapoznania czytelników „Pamiętnika Literackiego" $z$ jej niepospolitym darem obserwacji i zapamiętywania, odczuwania przyrody, talentem epickim, praca zawodowa związaną $z$ rolnictwem, ciekawa genealogia rodzinna sięgajaca XVIII w. ${ }^{53}$ Należy nadmienić, że pisarka, która zadebiutowała w wieku 51 lat opowiadaniem pt. Jeziora, opublikowanym w londyńskim tygodniku „Wiadomości” ${ }^{54}$, otrzymała prestiżowa nagrodę literacka tychże „Wiadomości” w 1964 r. za powieść wydana w 1963 r. pt. Wróble noce ${ }^{55}$. Zbiór opowiadań zatytułowany Droga do Braiłowa z 1959 r. przyniósł jej drugie miejsce w plebiscycie Radia Wolna Europa za najlepsza książkę roku. Pierwsze miejsce zdobył wtedy Czesław Miłosz za Rodzinna Europę. W 2005 r. otrzymała nagrodę ZPPnO za całokształt twórczości.

Czytelnikom „Pamiętnika Literackiego” przywróciła pamięć o poecie, dziennikarzu, prozaiku, krytyku, byłym żołnierzu 2 Korpusu Polskiego, nagle zmarłym na zawał serca w 1960 r. - Tadeuszu Sułkowskim. Przytoczyła zasłyszane opowieści o kilku epizodach $z$ jego biografii $z$ czasu, gdy na polecenie ówczesnego prezesa ZPPnO profesora Stanisława Strońskiego od marca 1948 r. pełnił funkcje administratora Domu Pisarza Polskiego przy Finchley Road $312 \mathrm{w}$ Londynie ${ }^{56}$. Ukazała go jako wielkiego kawalarza, opowiadając, jak wraz z Tadeuszem Nowakowskim w prima aprilis przeprowadził dla żartu wśród polskich aktorów casting przez fikcyjne studio filmowe, czego środowisko artystów nie mogło im darować. Należy dodać, że niezaradny życiowo Sułkowski poza tym pracował fizycznie w drukarni należącej do emigrantów z Jugosławii oraz Oficynie Poetów i Malarzy, prowadzonej przez przyjaciół poety Krystynę i Czesława Bednarczyków. Jego wiersze były drukowane w londyńskich „Wiadomościach” oraz paryskiej „Kulturze”, a w 1956 r. otrzymał nagrodę poetycka przyznana przez Towarzystwo Przyjaciół Kultury Polskiej w Glasgow. Rozgłośnia Polska Radia Wolna Europa nadawała jego felietony na tematy plastyczne, muzyczne i teatralne. W rocznicę jego śmierci właściciele Oficyny Malarzy i Poetów z dużą starannością edytorską wydali dwa, ilustrowane

\footnotetext{
53 Regina Wasiak-Taylor, „Ostatnia niezwykła kresowianka”, PL, t. 31, 2006, 83-92.

54 Konrad W. Tatarowski, "Ostatni rozdział literatury emigracyjnej - Irena Bączkowska”, Acta Universitatis Lodziensis. Folia Litteraria Polonica, z. 10, 2008, 167-171.

55 Regina Wasiak-Taylor, „Ostatnia niezwykła kresowianka”, 87. Wznowienie tej książki pod zmienionym tytułem: Letnie noce, (Londyn: Veritas, 1987).

56 Regina Wasiak-Taylor, „Był dom”, PL, t. 34, 2007, 93-100.
} 
przez Feliksa Topolskiego, tomiki z twórczością Sułkowskiego: poemat Tarcza i wiersze Dom złoty.

Z okazji jubileuszu 60-lecia funkcjonowania przypomniała czytelnikom historię ustanowionej w 1951 r. Nagrody Literackiej Zwiazku Pisarzy Polskich na Obczyźnie. Nagroda była próbą kontynuowania jednej $z$ form życia kulturalnego, które przerwała druga wojna światowa, a na emigracji ewoluowała, rozrastając się do kilku laurów ufundowanych przez poszczególne osoby - np. przyznawanej od 1954 r. Nagrody Młodych dla dobrze zapowiadających się poetów, prozaików, publicystów czy od 1957 r. Nagrody im. Herminii Naglerowej za najlepsza ksiażkę minionego roku wydawniczego ${ }^{57}$. Wyróżnienia te miały „nadawać życiu literackiemu na uchodźstwie cech normalności" ${ }^{58}$. Idea powołania pierwotnej nagrody było „popieranie literatury polskiej powstającej w wolnym świecie, zapewnienie jej swobodnego rozwoju, aby mogła wyrażać i podnosić na duchu świadomość narodu i świadczyć o nim wśród obcych społeczeństw”59. Poza tym wydrukowano w „Pamiętniku” listę laureatów nagród literackich ZPPnO w latach 1951-2011 ${ }^{60}$. Był to skrócony przedruk jubileuszowej publikacji zwartej opracowanej przez Reginę Wasiak-Taylor, zatytułowanej Dzieje Nagrody Literackiej Zwiazku Pisarzy Polskich na Obczyźnie 1951-2011, w pięknym opracowaniu graficznym Danuty Laskowskiej-Osieckiej, wydanej w Londynie 2011 r. nakładem ZPPnO. Jej głos w dyskusji na ten temat był jednym $z$ wielu podczas uroczystej sesji odczytowej $z$ udziałem kilku laureatów $z$ poprzednich lat urządzonej 2 października 2011 r. w Londynie ${ }^{61}$. Jubileusz Nagrody ZPPnO odbył się pod patronatem Ambasady RP w Londynie i Stowarzyszenia „Wspólnota Polska" i zakończony został uroczysta kolacją.

Wasiak-Taylor jest autorką odczytów, które wygłaszała na różnych wieczorach literackich. Niektóre zostały opublikowane w „Pamiętniku Literackim”. Przykładowo 26 października 2004 r. w POSK-u odbyło się spotkanie poświęcone wydawnictwu Krystyny i Czesława Bednarczyków - Oficynie Poetów i Malarzy ${ }^{62}$, słynnej

\footnotetext{
57 Regina Wasiak-Taylor, „Zaszczyt wielki, korzyść mniejsza”, PL, t. 42, 2011, 19-25.

58 Ibidem, 20.

59 Ibidem, 20-21.

60 Regina Wasiak-Taylor, „Laureaci nagród literackich ZPPnO”, PL, t. 42, 2011, 49-61.

61 „Kronika Związk”, PL, t. 43/44, 2012, 204-205.

62 O Oficynie Poetów i Malarzy C. i K. Bednarczyków ukazało się wiele publikacji w kraju i na emigracji, np.: Michał Sambor, „Oficyna Poetów i Malarzy”, Kultura, nr 4, 1953, 127-130;
} 
„Drukarni pod mostem” w Londynie, z udziałem Mariana Pankowskiego i dr Alicji Moskalowej, na którym Regina Wasiak-Taylor zaprezentowała drugie półwiecze tej wyjątkowej firmy wydawniczej ${ }^{63}$.

Reginie Wasiak-Taylor jako doskonale zorientowanej w środowisku polskich emigrantów i ich dokonań literacko-artystycznych, a także przygotowanej $z$ racji wykształcenia i zamiłowania, bywaja powierzane laudacje na cześć osób $z$ okazji przyznania im różnych nagród. W 2008 r. w imieniu Senatu PUNO prof. Halina Taborska zaproponowała jej wygłoszenie mowy pochwalnej na okoliczność wyróżnienia Krystyny Bednarczyk doktoratem honoris causa tej uczelni. Wasiak-Taylor nie kryła, że była „oszołomiona tym zaszczytem i onieśmielona wobec zadania, a zwłaszcza wobec tej plejady pisarzy, których Dostojna Laureatka wydawała przez sześćdziesiąt lat w Oficynie Poetów i Malarzy"64. Laudację wygłosiła podczas inauguracji Roku Akademickiego PUNO w Londynie 23 października 2008 r. Zawarła w niej wspomnienie swojego pierwszego kontaktu z Drukarnia pod mostem i Bednarczykami, zaprezentowała edytowane przez nich bibliofilskie tomiki, współpracę $z$ poetami i artystami plastykami, twórczość nagrodzonej, konstatując, że:

Stefan Legeżyński, „15 lat Oficyny Poetów i Malarzy”, Wiadomości, nr 968, 1964, 4; „Brzękowski i "Oficyna Poetów", Twórczość, nr 4, 1968, 142-144; Andrzej Krzysztof Waśkiewicz, „Oficyna Poetów“ czyli o mecenacie”, Życie Literackie, nr 15(1159), 1974, 4; „Opium. Z Krystyną i Czesławem Bednarczykami założycielami i właścicielami Oficyny Poetów i Malarzy rozmawia A. Ziembicki”, Nowe Książki, nr 10, 1981, 1-6; Andrzej Kłossowski, Na obczyźnie. Ludzie polskiej książki, (Wrocław: Zakład Narodowy im. Ossolińskich, 1984), 305-312; Ewa Pytasz, Marek Pytasz, Bednarczykowie jako wydawcy (rekonesans), w: Tadeusz Bujnicki, Wojciech Wyskiel (red.), Pisarz na obczyźnie, (Wrocław: Zakład Narodowy im. Ossolińskich, 1985); Krystyna Bednarczyk, „Między Kulturą a Wiadomościami. Rozmowę przeprowadził J. Kryszak”, Kwartalnik Artystyczny, nr 3, 1996, 70-75; Józef Koźmiński, „ "Oficyna Poetów“ i malarze”, Kwartalnik Artystyczny, nr 3, 1996, 76-82; Czesław Bednarczyk, „Autoportret: audycja Konrada Tatarowskiego z cyklu "Polscy twórcy na emigracji» z 23 XI 1991 r.: $z$ taśmoteki Rozgłośni Polskiej RWE”, Tygiel Kultury, nr 4, 1997, 88-92; „Historia Oficyny. Krystyna Bednarczyk, Czesław Bednarczyk. Rozmowę przeprowadził M. Pytasz”, Fraza, nr 1-2, 1998, 112-118; „Nie zmarnowany czas. Krystyna Bednarczykowa. Rozmowę przeprowadził K. Dorosz, P. Tański”, Przeglad Powszechny, nr 2, 2003, 172-180; Adam Kochańczyk, „Piękne książki Bednarczyków”, Akcent, nr 1-2, 2004, 273-275; Julia Hartwig, „Drukarnia pod mostem”, Więź, nr 2, 2004, 137-140; Pamiętnik Literacki, t. 36, 2007 - numer specjalny poświęcony wydawnictwu Bednarczyków; Jolanta Chwastyk-Kowalczyk, „"Oficyna Poetów“ niszowy kwartalnik literacko-artystyczny (1966-1980)", Rocznik Historii Prasy Polskiej, t. 16, z. 2 (3), 2013, 117-132.

63 Regina Wasiak-Taylor, „Drugie półwiecze Oficyny Poetów i Malarzy”, PL, t. 30, 2005, 49-55.

64 Regina Wasiak-Taylor, „Doktor honoris causa Polskiego Uniwersytetu na Obczyźnie dla Krystyny Bednarczyk - poetki, drukarza i wydawcy", PL, t. 36, 2008, 9-15. 
Bednarczykowie stworzyli na emigracji ważna instytucję kulturalna, która oprócz wydawnictwa i drukarni dała środowisku salon literacki. Wszystkie drogi prowadziły poetów i pisarzy, dziennikarzy i publicystów, miłośników książki różnych pokoleń i generacji do „drukarni podmostowej i do przyjaznego domu Bednarczyków na Colindeep”, w którym raz na miesiąc odbywały się wieczory literackie. ... Przyznanie Krystynie Bednarczyk godności doktora honoris causa Polskiego Uniwersytetu na Obczyźnie jest uhonorowaniem jej zasług w ratowaniu twórczości literackiej powstałej poza krajem i w utrzymywaniu jedności literatury polskiej. Doctoranda Clarissima! ${ }^{65}$

Wspólnie z Andrzejem Krzeczunowiczem Regina Wasiak-Taylor prowadziła 28 października 2008 r. w Sali Teatralnej POSK spotkanie z okazji jubileuszu 60-lecia Oficyny Poetów i Malarzy oraz benefisu $z$ okazji 85. rocznicy urodzin jej współzałożycielki Krystyny Bednarczyk ${ }^{66}$. Przygotowanie tej imprezy zajęło sekretarz ZPPnO dziewięć miesięcy.

Do tematu tego wydawnictwa powróciła po śmierci Krystyny Bednarczyk w 2011 r. w cyklu artykułów poświęconych archiwum Oficyny Poetów i Malarzy, przed przekazaniem go - zgodnie $z$ wolą właścicieli - Uniwersytetowi Jagiellońskiemu w Krakowie, gdzie miało zostać uporzacklkowane i udostępnione. Wykonawczynią testamentu Bednarczyków była Cyryl Topolska, druga żona Feliksa Topolskiego. Regina Wasiak-Taylor opisała swoje wizyty w domu Bednarczyków w latach 2011-201267.

W 2014 r. opracowała wydarzenia o charakterze literackim na Polskim Uniwersytecie na Obczyźnie w Londynie ${ }^{68}$.

Inicjuje i prowadzi promocje książek polskich autorów oraz moderuje inne spotkania życia literackiego i naukowego w Ambasadzie RP w Londynie, na Międzynarodowych Targach Ksiażki w Warszawie (po raz pierwszy 18-21 maja 2006) oraz na imprezach literackich w różnych miejscach. Informacje na ten temat zainteresowani zawsze odnajda w „Kronice Związku” w poszczególnych numerach „Pamiętnika Literackiego"69.

\footnotetext{
65 Ibidem, 14.

66 „Kronika Zwiąku”, PL, t. 37, 2009, 148.

67 Regina Wasiak-Taylor, „Archiwum Oficyny Poetówi Malarzy opuszcza Londyn”, $P L$, t. 43/44, 2012, 59-72; eadem, „Archiwum Oficyny Poetów i Malarzy opuszcza Londyn cd.”, PL, t. 45/46, 2013, 83-93.

68 Regina Wasiak-Taylor, „Polski Uniwersytet na Obczyźnie - wydarzenia o charakterze literackim w 2014 roku", $P L$, t. 48, 2014, 143.

69 „Kronika Zwiąku”, PL, t. 34, 2007, 150.
} 
15 marca 2015 r. w POSK-u odbyła się promocja książki Andrzeja Krzeczunowicza pt. Bołszowce. Wspomnienia $z$ dziecinstwa na Kresach ${ }^{70}$. W programie czynny udział wzięła m.in. Regina Wasiak-Taylor. Promocji towarzyszyło stoisko ze sprzedaża promowanej książki, sprzedano wszystkie egzemplarze $z$ dużym zyskiem dla ZPPnO. Dziennikarka prowadziła w tym samym roku 12 kwietnia w Jazz Café w POSK-u promocję książki Piotra Surmaczyńskiego pt. Wyspa dreszczowców $w^{71}$.

Kalendarz imprez artystyczno-muzyczno-naukowych Reginy Wasiak-Taylor jest zawsze napięty - od organizacji promocji książek, koncertów jazzowych z czytaniem poezji, gali wręczania nagród Związku Pisarzy Polskich na Obczyźnie, poprzez spotkania autorskie czy wykłady ${ }^{72}$.

Należy podkreślić, że Sejm Rzeczypospolitej Polskiej uchwalił rok 2019 Rokiem Gustawa Herlinga-Grudzińskiego, uznajac go $z a$,jednego $z$ najwybitniejszych pisarzy polskich XX wieku. Jego losy i twórczość stanowia świadectwo cierpień i czynów człowieka, któremu przyszło przeżyć czasy totalitarnej przemocy i kryzysu wartości" ${ }^{\prime 3}$. $Z$ inicjatywy Wasiak-Taylor środowisko ZPPnO było jednym $z$ nielicznych, które poświęciło pisarzowi większą uwagę. W 27. Salonie Literackim uczestnicy usłyszeli dwugłos o twórczości autora Dziennika pisanego noca: z jednej strony historyka prof. Rafała Habielskiego, a $z$ drugiej - literaturoznawcy dr. Jacka Hajduka. $Z$ rozmów w tym zespole zrodził się pomysł przygotowania monograficznego, poświęconego Gustawowi Herlingowi-Grudzińskiemu grudniowego tomu LVIII z 2019 r. „Pamiętnika Literackiego”, o czym dowiaduje się czytelnik $z$ przesłania prezes $Z \mathrm{PPnO}$, zamieszczonego w uwagach „Od redakcji”"

Dziennikarka publikuje czasami tzw. sylwetki, będące pożegnaniem znanych i szanowanych $\mathrm{w}$ środowisku emigracyjnym literatów lub innych osób. Jedną $z$ nich poświęciła nagrodzonemu przez ZPPnO w 2001 r. za szerzenie polskich osiagnięć kulturalnych w RPA ks. dr. infułatowi Janowi Jaworskiemu. Ksiądz - długoletni rektor Polskiej Misji Katolickiej w Republice Południowej

70 „Kronika Związku”, PL, t. 49, 2015, 177.

71 Ibidem.

72 Np.: „Kronika Związku”, PL, t. 57, 2019, 277; Grażyna Maxwell, „Związek Pisarzy w delegacji”, $P L$, t. 57, 2019, 283-286; „Kronika Zwiąku”, PL, t. 57, 2019, 279.

73 Regina Wasiak-Taylor, „Od redakcji”, PL, t. 58, 2019, 7.

74 Ibidem. 
Afryki (do 1999 r. do przejścia na emeryturę) - zmarł w 2008 r. w Johannesburgu ${ }^{75}$.

Napisała także wzruszające wspomnienie o Zbigniewie Makowieckim po jego odejściu w 2017 r., człowieku, który „sam pisarzem nie był, o książkach nie pisał, ale się nimi otaczał", przedstawiajac go jako przyjaciela i wiernego druha Związu Pisarzy Polskich na Obczyźnie, potrafiącego jeszcze w wieku 94 lat cytować $z$ pamięci fragmenty $W$ poszukiwaniu straconego czasu Prousta także w języku francuskim ${ }^{76}$.

Regina Wasiak-Taylor jest autorka recenzji książek $z$ wielu dziedzin, które są w kręgu jej zainteresowań - los emigrantów politycznych, reportaże wspomnieniowe, literatura faktu ${ }^{77}$. Nieukrywana miłościa darzy szczególnie balet ${ }^{78}$. Ma na swoim koncie również prace redaktorskie przy edycji publikacji zwartych. Przygotowała do druku i wstępem opatrzyła: Stefana Andrzeja Borsukiewicza Powroty (Londyn: Zwiazek Polskich Spadochroniarzy, 1987), Ireny Baczkowkiej Letnie noce (Londyn: Veritas Foundation Publication Centre, 2005), IV wydanie ksiażki monograficznej Danuty Waszczukówny-Kamienieckiej Brześć. Niezapomniane miasto (Londyn: Danuta Waszczukówna-Kamieniecka, 1997). Jest współautorką ksiażki wspomnieniowej Włady Majewskiej $Z$ Lwowskiej Fali do Radia Wolna Europa (Wrocław: Wydawnictwo Dolnoślaskie, 2005).

Jako autorka wydała samodzielnie: wspomniane wcześniej Dzieje Nagrody Literackiej ZPPnO 1951-2011 (Londyn: Związek Pisarzy Polskich na Obczyźnie, 2011), Ojczyzna literatura (Londyn: Oficyna Poetów i Malarzy, 2013) ${ }^{79}$, Alfabet wspomnień Szymona Zaremby. II Rzeczpospolita, II wojna światowa, emigracja, (Londyn: Zwiazek Pisarzy Polskich na Obczyźnie, 2015). Fragmenty Alfabetu wspomnień drukowane były wcześniej w „Pamiętniku Literackim" $"$.

\footnotetext{
75 Regina Wasiak-Taylor, „Żegnaj, drogi Przyjacielu!”, PL, t. 38, 2009, 151-152.

76 Regina Wasiak-Taylor, „Wspomnienie o Zbigniewie Makowieckim 1917-2017”, PL, t. 54, 2017, 269-271.

77 Regina Wasiak-Taylor, „Dla przyjaciół za wierność, PL, t. 47, 2014, 147-151; eadem, „Historie prawdziwe”, PL, t. 52, 2016, 206-211.

78 Regina Wasiak-Taylor, „O balecie sprzed 150 lat”, $P L$, t. 43/44, 2012, 186-189.

79 Reakcję tzw. polskiego Londynu zob.: J. Chwastyk-Kowalczyk, „Ksiażka, która otworzyła puszkę Pandory w "polskim Londynie» w XXI wieku”, w: Teresa Wilkoń (red.), O etosie książki. Studia $z$ dziejów bibliotek $i$ kultury czytelniczej, Katowice: Wydawnictwo Uniwersytetu Śląskiego, 2017), 528-539.

80 Regina Wasiak-Taylor, „Alfabet wspomnień Szymona Zaremby”, PL, t. 49, 2015, 143-153.
} 
Kiedy jesienia 2013 r. ukazała się w Londynie publikacja Reginy Wasiak-Taylor pt. Ojczyzna literatura. O środowisku skupionym wokół Zwiazku Pisarzy na Obczyźnie, wydana - jak czytamy w kolofonie - jako ostatnia pozycja działającej w Londynie w latach 1949-2011 Oficyny Poetów i Malarzy, nikt nie przypuszczał, że otworzy puszkę Pandory w polskim Londynie w XXI w., wywoła falę niewybrednych ataków na autorkę oraz doprowadzi do eskalacji konfliktu o podłożu polityczno-osobistym $z$ jej adwersarzami na forum publicznym, przede wszystkim w emigracyjnej prasie. Nadmienić należy, że pozytywne recenzje wydawnicze publikacji przed jej edycja i po niej napisali $z$ Wiednia prof. ks. Bonifacy Miązek oraz $z$ Polski - prof. dr hab. Jolanta Chwastyk-Kowalczyk ${ }^{81}$.

Regina Wasiak-Taylor została przyjęta w poczet członków Związku Literatów Polskich na Obczyźnie w Londynie - przypomnijmy - w latach 80. XX w. Przebywając na urlopie, po 13 grudnia 1981 r. postanowiła zostać w Zjednoczonym Królestwie, co ułatwiało „wyjątkowe pozwolenie na pobyt” wydawane Polakom przez władze brytyjskie. Gdy było to już możliwe, kilkakrotnie przyjeżdżała do Polski opiekować się chora mamą. W kraju była wielokrotnie nękana przez funkcjonariuszy wywiadu Ministerstwa Spraw Wewnętrznych. Po rozwiązaniu problemów osobistych w Wielkiej Brytanii zajęła się organizowaniem i promocja polskiego życia literackiego na obczyźnie - praca dla ZPPnO, Scena Poetycka POSK-u $i$ in. Należy do przemijającego świata wielkich społeczników, działających dla dobra wspólnego na wielu płaszczyznach. Do ZPPnO wprowadził ją dr Józef Garliński, który był pod wrażeniem jej zapału do pracy i działania na rzecz środowiska. Autorka zna londyńskie polskie środowisko emigracyjne. Przez wiele lat przyjaźniła się również z małżeństwem Bednarczyków.

Przez osiem lat materiały pokazane przez Reginę Wasiak-Taylor ówczesnemu prezesowi ZPPnO Józefowi Garlińskiemu czekały na opracowanie redakcyjne. Zgodę na ich wydanie w Oficynie Poetów i Malarzy wyraziła Krystyna Bednarczyk, która niestety

\footnotetext{
81 Bonifacy Miązek, „Książka ważna i potrzebna”, PL, t. 47, 2013, 162-170; Jolanta Chwastyk-Kowalczyk (rec.), „Regina Wasiak-Taylor, Ojczyzna literatura. O środowisku skupionym wokół Związku Pisarzy Polskich na Obczyźnie, Londyn 2013, Oficyna Poetów i Malarzy, ss. 288, ISBN: 978-0-9570372-1-2", Rocznik Bibliologiczno-Prasoznawczy, nr 6/17, 2014, 315318; eadem (rec.), „Regina Wasiak-Taylor, Ojczyzna literatura. O środowisku skupionym wokół Związku Pisarzy na Obczyźnie, Oficyna Poetów i Malarzy, Londyn 2013, 285 ss., 3 nlb.”, Zeszyty Naukowe PUNO. Seria trzecia, nr 2, 2014, 283-286.
} 
zmarła w kwietniu 2011 r., nie doczekawszy ostatniej publikacji edytowanej przez jej oficynę. Zamysłem Krystyny Bednarczykowej było wydać tę książkę na ręcznej maszynie „Adanie”, wybrała papier, ulubiony krój czcionki - Garamond, kilkanaście rysunków i grafik, określiła nakład. Ale w 2005 r. została prezesem ZPPnO, pochłonęły ja sprawy organizacyjne, potem przyszła choroba. Dwa lata po jej śmierci Wasiak-Taylor odkurzyła teczkę z zebranym materiałem i postanowiła $z$ zachowaniem sugestii Bednarczykowej wydać ksiażkę. Skorzystała $z$ pomocy drukarza Jana Kapanowskiego, któremu Krystyna Bednarczyk „powierzała w ostatnich latach przygotowywane przez siebie $z$ rzadka bibliofilskie wydania książek polskich i angielskich" 82 .

Na publikację złożyło się 14 szkiców i 13 wywiadów - głównie $z$ polskimi literatami żyjącymi na emigracji, których autorka znała osobiście, poza Sergiuszem Piaseckim, ale także $z$ uczonymi, wydawcami, bibliotekarzami (Zdzisław Jagodziński), autorami tekstów piosenek (Ref-Ren, czyli Feliks Konarski), artystami estradowymi (Włada Majewska), fotografikami (Juliusz Englert), jak również prezentacja ważnych instytucji emigracyjnych - Oficyna Poetów i Malarzy. Wiele z nich ukazało się wcześniej w londyńskich pismach - „Pamiętniku Literackim”, sobotnim kulturalno-społecznym dodatku do „Dziennika Polskiego i Dziennika Żołnierza” - „Tygodniu Polskim", zostały wygłoszone lub wykorzystane w programach teatralnych. Jednak autorka odświeżyła je, przeredagowała, uzupełniła lub napisała od nowa. Dziewicze są eseje o Stanisławie Balińskim, Jerzym Pietrkiewiczu czy rozmowy z przyjacielem Bolesławem Taborskim i z Rosemary Hunt. W „Przedmowie” Wasiak-Taylor pisze: „przez 30 lat życia poza krajem każdy z poruszonych tutaj tematów, przerabiałam wielokrotnie. O ulubionej Oficynie Poetów i Malarzy pisałam kilkadziesiąt razy. Ze swoimi bohaterami na ogół się nie rozstaję, dopisuję do tematów znanych kolejne rozdziały. Przykładem tej metody są dwa teksty o Irenie Bączkowskiej - artykuł i wywiad"83.

Cały materiał ułożony jest chronologicznie według dat ich opublikowania lub powstania. Podzielony został na dwie części: Szkice i Wywiady. Poznajemy barwne sylwetki polskiego świata

\footnotetext{
82 Regina Wasiak-Taylor, Ojczyzna literatura. O środowisku skupionym wokół Związku Pisarzy na Obczyźnie, (Londyn: Oficyna Poetów i Malarzy, 2013), 9.

83 Ibidem, 10.
} 
najszerzej pojętej kultury polskich uchodźców, żyjących poza krajem. Wielu $z$ nich pozostanie już tylko w naszej pamięci: Irena $\mathrm{Za}-$ błocka-Bączkowska, Stanisław Gliwa, Zdzisław Jagodziński, Józef Garliński, Alicja Iwańska, Jerzy Kulczycki, Bolesław Taborski, Marta Reszczyńska-Stypińska, Zbigniew Zaniewicki. Postaciami centralnymi tego opracowania sa laureaci rozmaitych nagród przyznawanych przez Związek Pisarzy Polskich na Obczyźnie: Stanisław Baliński, Florian Śmieja, Marian Hemar, Krzysztof Głuchowski, Mieczysław Paszkiewicz, Zbigniew S. Siemaszko, Aleksandra Ziółkowska-Boehm.

Ważna częścia tej publikacji jest Nota biograficzna, która może uchodzić za najbardziej aktualną bazę danych na temat polskiego życia literacko-naukowego w Wielkiej Brytanii.

Książka urzeka klimatem, dowcipem, serdeczną uwaga interlokutorów lub autorki, przytaczane sa anegdoty, perypetie bohaterów, mało znane fakty, drobiazgi, szczegóły, które składają się na holistyczny puzzle polskiej kultury na obczyźnie. Napisana jest znakomita, barwną polszczyzna, w której trudno doszukać się śladów tak wielu lat życia autorki poza Polską. Trudno się dziwić śp. Władysławowi Bartoszewskiemu, który serdecznie pogratulował autorce droga mailowa tej publikacji. Już dawno nie zdarzyło mi się czytać ksiażki, która mogłabym z tak czystym sumieniem polecić wszystkim humanistom bez względu na ich specjalizację oraz osobom zainteresowanym po prostu nietuzinkowym światem funkcjonowania naszej kultury na obczyźnie.

Nie wszyscy jednak podzielają opinie recenzentów. I byłby to naturalny stan rzeczy, gdyby nie sposób i skala osobistych ataków na autorkę i jej dzieło przeprowadzanych na łamach polskiej prasy emigracyjnej ukazującej się w Wielkiej Brytanii. Do zdecydowanych adwersarzy autorki i wspomnianej publikacji należała przede wszystkim dr Alina Siomkajło ${ }^{84}$, podająca się za historyka literatury i krytyka literackiego, absolwentka polonistyki na KUL-u, od 2010 r. prezes działającego w opozycji do Zwiazku Pisarzy Polskich na Obczyźnie - Stowarzyszenia Pisarzy Polskich za Granica z sie-

\footnotetext{
84 Wpis dostępny na stronie internetowej [online] [dostęp: 12.09.2015]. Dostępny w World Wide Web: <http://www.alinasiomkajło.iap.pl/pl>; Alina Siomkajło zmarła w 2015 r. w Londynie.
} 
dziba w Londynie ${ }^{85}$. Uważała ona, że Wasiak-Taylor „przelewa na siebie profity płynace $z$ prestiżu śp. Krystyny i Czesława Bednarczyków oraz prowadzonej przez nich Oficyny Poetów i Malarzy, ... że nie wykazuje się w książce posiadaniem dokumentu - goodwill - świadczaccego o nabyciu praw do używania nazwy Oficyna Poetów i Malarzy po śmierci właścicieli ${ }^{86}$ wydawnictwa ..." ${ }^{87}$. Pada także zarzut łamania przez nią praw autorskich, ponieważ wykorzystała ryciny, grafiki i typografie Stanisława Gliwy, Mariana Kościałkowskiego, Mariana Szyszko-Bohusza, Franciszka Themersona ${ }^{88}$, Feliksa Topolskiego, Marka Żuławskiego. Jest on bezzasadny, bowiem Wasiak-Taylor wyraźnie odnotowała na s. 287, że zamieszczone prace pochodza $z$ archiwum Oficyny Poetów i Malarzy. Siomkajło stwierdziła dalej, że „Światłem w mroku Ojczyzna literatura nie jest ... Czytelnikowi o szerszych horyzontach literackich, historykowi, badaczowi - książka dopuszczająca się bałamucenia faktów, prymitywizowania istniejących interpretacji, budząca różnej natury poważne zastrzeżenia, nie przyniesie nic nowego" ${ }^{89}$. Nie szczędziła czytelnikowi szczegółów z życia prywatnego autorki, określając ja, m.in. jako „rabusia archiwum Oficyny Poetów i Malarzy”, „pseudoemigrantkę”, która „bezkrytycznym mandatem zaufania obdarzył prezes ZPPnO Józef Garliński"91. Zarzut zdumiewajacy, ponieważ każdy badacz polskiej diaspory „pokolenia niezłomnych” na Wyspach Brytyjskich doskonale wie, że zdobycie zaufania przez nowo przybyłych $z$ kraju w tej grupie nie jest łatwe i natrafia do tej pory na wiele trudności oraz zdecydowane dystansowanie się tego środowiska. Jako kuriozalne odebrać możemy następne doniesienia Siomkajło:

Że na zabliźnieniu realiów osiedlenia się na Wyspach, mogło Reginie Wasiak-Taylor zależeć, okazało się w czerwcu 2009 roku po odtajnieniu przez Zbigniewa Bereszyńskiego jej teczki w SB. Wydało się, iż przebywająca w Londynie w okolicy stanu wojennego

\footnotetext{
85 Alina Siomkajło wydawała jako redaktor naczelna od 2010 r. w Londynie „Ekspresje. Rocznik Literacko-Społeczny Stowarzyszenia Pisarzy Polskich za Granica”. W 2015 r. ukazał się 5 numer.

86 Czesław Bednarczyk zmarł w 1994 r., a Krystyna Bednarczyk w 2011.

87 A. Siomkajło, „Przygoda wydawnicza. Tylko dla żądnych świadomości”, Nowy Czas, nr 7 (205), 2014, 20.

88 W artykule jest błędnie mowa o Franciszku Themersonie, a chodzi o Franciszkę Themerson.

89 Alina Siomkajło, „Przygoda wydawnicza”, 20.

90 Alina Siomkajło, „Poproszę o receptę”, Nowy Czas, nr 11/12 (209-210), 2014, 3.

91 Alina Siomkajło, „Przygoda wydawnicza”, 20.
} 
pseudoemigrantka zawarła pierwsze małżeństwo z Brytyjczykiem i kursuje między Londynem a Polska, nadal spotyka się w kraju $z$ prowadzącym ja oficerem SB, że stan wojenny nie przeszkodził jej w kontynuowaniu dialogu operacyjnego ${ }^{92}$.

Siomkajło oskarżyła Wasiak-Taylor o sfałszowanie pozytywnej opinii o mającej już swój zrąb książce, napisaną w styczniu 2005 r. przez Józefa Garlińskiego, zapewniajac: „Zrobiłam kopię tej cenzurki i dobrze ją schowałam. Kiedyś wypłynie na powierzchnię niesfornych papierów. Podróbki tego samego pisma mają prawdopodobnie fundacje, w których autorka składała podanie o dotacje na wydanie książi”93. Siomkajło, zwolenniczka tygodnika „Do Rzeczy" (co sama przyznała), szydziła także $z$ autorów (w tym ze stopniami naukowymi), którzy napisali merytoryczne i pochlebne recenzje publikacji Ojczyzna literatura, zamieszczone w prasie emigracyjnej w Wielkiej Brytanii oraz w Polsce lub przy okazji wymienili tę książkę $z$ pozytywnym akcentem. Recenzyjnymi „pustakami”, „laurkowym chórem”94 nazwała Mieczysława Orskiego, Piotra Gulbickiego, Andrzeja Konikiewicza, Krzysztofa Masłonia, Jerzego Krzyżanowskiego, Wojciecha Kaliszewskiego ${ }^{95}$.

Na ten „beztroski wylew insynuacji, ... pouczeń i pomówień ... pod adresem Reginy Wasiak-Taylor” odpowiedział w londyńskim miesięczniku „Nowy Czas” slawista ks. prof. Bonifacy Miązk ${ }^{96}$. Odpierając zarzut zawłaszczenia przez autorkę tradycji wydawnictwa Bednarczyków, stwierdził jako świadek powstawania tej książki i recenzent, że miała ona moralne prawo wydać swoja publikację w Oficynie Poetów i Malarzy, ponieważ Krystyna Bednarczyk przyjęła ją do druku. Potwierdził za autorka Przedmowy, iż to ona

92 Ibidem.

93 Ibidem.

94 Ibidem, 21.

95 Mieczysław Orski, „Londyńska Ojczyzna literatury”, Odra, nr 2, 2014, 131-132; zob. Wpis dostępny na blogu [online] [dostęp: 14.09.2015]. Dostępny w World Wide Web: <http:// www.taylor.blogspot.com/2014/05/gosy-o-ksiazce-mieczysaw-orski.html>; Piotr Gulbicki, „W poszukiwaniu dawnych wielkości”, Dziennik Polski i Dziennik Żołnierza, nr 77, 2014, dodatek Tydzień Polski, nr 16, 2014, 8; „Książka cenna i rzadka”, Nasza Polska, nr 26, 2014, 9; Andrzej Konikiewicz, „Podwójne epitafium”, Rzeczpospolita, 15.04.2014 [online] [dostęp: 14.09.2015]. Dostępny w World Wide Web: http://www.rp.pl/artykul/9148,1102083-Podwojne-epitafium.html; Krzysztof Masłoń, „Emigracyjny przypadek, Do Rzeczy, nr 28, 2014, 47; Jerzy Krzyżanowski, „Ojczyzna literatura”, Przegląd Polski-dodatek kulturalny do nowojorskiego Nowego Dziennika, kwiecień, 2014, 9; Wojciech Kaliszewski, „Ostatnie", Nowe Książi, nr 8, 2014, 64-65.

96 Ks. Bonifacy Miązek, „O naszym środowisku”, Nowy Czas, nr 8 (206), 2014, 2. 
właśnie „wybrała papier, swój ulubiony krój czcionki - garamond, kilkanaście rysunków i grafik, określiła nakład ..."97 i że nigdy tej decyzji nie zmieniła ani nie odwołała. Uczony powołał się na jedna $z$ rozmów telefonicznych odbytych z Krystyna Bednarczyk, kiedy przebywała już w Domu Opieki im. św. Ojca Kolbe w Londynie, podczas której zapytał o stan zaawansowania redakcyjnego książki Reginy Wasiak-Taylor. Właścicielka Oficyny stwierdziła, że „Regina ciagle jeszcze poprawia, dopisuje i to może trwać wiecznie" ${ }^{98}$. Napisał, że polski Londyn pamięta, że po śmierci Czesława Bednarczyka Regina Wasiak-Taylor była dla Krystyny Bednarczyk wielka pomoca i podpora w życiu prywatnym oraz zwiąkowym. Wspomniał także, że poetka darzyła autorkę książki Ojczyzna literatura szacunkiem i zaufaniem, pozwalając się doglądać w Domu Opieki, że to Wasiak-Taylor wygłosiła laudację z okazji przyznania Krystynie Bednarczyk doktoratu honoris causa przez Polski Uniwersytet na Obczyźnie w Londynie oraz była inicjatorem i organizatorem „Wieczoru 60 lat Oficyny" w 2008 r. Ksiądz przyznał, że nigdy nie słyszał od Krystyny Bednarczyk choćby wzmianki o Alinie Siomkajło. Ubolewa, że nauczyciel akademicki, za jakiego się uważa Siomkajło, tak agresywnie, nie przebierając w słowach, „wylewa żółć i wali na odlew”, zamiast dokonać rzetelnej analizy merytorycznej. „Nie ma tu ani filologicznej precyzji, ani literackiej kultury"99, ani obiektywizmu. Uważa, że Siomkajło świadomie szkaluje pomówieniami o współpracę $z$ SB autorkę książki Ojczyzna literatura, przypominając zarazem, że takie teczki ma każdy, kto wyjeżdżał w czasach PRL-u za granicę. A nagminne produkowanie zeznań, doniesień i protokołów przez funkcjonariuszy jest wszystkim znane. Pomówienie Wasiak-Taylor o próbę dokonania rozłamu w ZPPnO Miąek uważa za przewrotne, bowiem to właśnie dr Siomkajło próbowała rozbić Związek. Należy zaznaczyć, że o fakcie rozstania ze ZPPnO (istniejącym od 1946 r. w Londynie) Siomkajło, a także skreślenia jej z zespołu redakcyjnego „Pamiętnika Literackiego” w 2008 r. (organu ZPPnO utworzonego w 1976 r.) przez ówczesnego prezesa - Krystynę Bednarczyk - napisała w liście do Redakcji „Nowego Czasu" wieloletnia przyjaciółka poetki Jolanta Lane ${ }^{100}$.

\footnotetext{
97 Ibidem, 2.

98 Ibidem.

99 Ibidem.

100 Jolanta Lane, „Nie wylewajmy dziecka z kapiela”, Nowy Czas, nr 11/12 (209-210), 2014, 3-4.
} 
W polemikę $z$ ks. prof. Bonifacym Miązkiem włączył się redaktor naczelny i właściciel „Nowego Czasu” Grzegorz Małkiewicz, broniąc stanowiska Aliny Siomkajło ${ }^{101}$. Pośrednio zasugerował w niej także Wasiak-Taylor wystapienie na drogę sadowa, by tam dowiodła, że nie ma przeszłości agenturalnej. Redakcja miesięcznika nie zgodziła się także $z$ opinią Jolanty Lane, która stwierdziła, że o wartości unicestwionej na emigracji na Wyspach książki „nie powinna przesądzać Alina Siomkajło i osoby nie mające wiele wspólnego z Oficyną Poetów i Malarzy"102. Małkiewicz przytoczył za to wypowiedź Siomkajło, która stwierdziła, że:

$Z$ właścicielka OPiM wiodłyśmy długie rozmowy. Prosiła, bym była jednym $z$ wykonawców jej testamentu - nie podjęłam się tej roli. Odwiedzała mnie, gdy czuła się osamotniona. W darowanych mi jej Wierszach wybranych pozostał ślad jednego $z$ naszych $u$ mnie spotkań: „Drogiej Pani Alinie Siomkajło z podziękowaniem za miły ostatni dzień 2006 roku - Krystyna Bednarczyk". Opowiadalam kiedyś p. Krystynie, $z$ jakim narażeniem Hanna Świderska przemycała $z$ Kraju zakazane druki. Mocno zaprotestowała: - To nieprawda! Ja wanami woziłam książki do Polski i z powrotem i nikt mnie nie kontrolował. Zdobyłam się na ripostę - Bo u Pani miesiącami mieszkał Kryszak... [pracownik naukowy Uniwersytetu Mikołaja Kopernika w Toruniu, który prowadził w Londynie długoletnie badania nad Emigracja Niepodległościowa, okazał się tajnym współpracownikiem SB - red. $]^{103}$.

Uroczysta promocja książki Ojczyzna literatura odbyła się 19 marca 2014 r. w Ambasadzie RP w Londynie. Impreza oraz idea powstania samej ksiażki mało przychylnie została opisana przez Teresę Bazarnik - współwłaścicielkę „Nowego Czasu”, prywatnie żonę Grzegorza Małkiewicza. Dziennikarka skrytykowała „górnolotna" laudację prof. Ewy Lewandowskiej-Tarasiuk, która za atut publikacji uznała jej różnorodność gatunkową ${ }^{104}$. Bazarnik oczekiwała od Wasiak-Taylor „spójnej opowieści, że ... przedstawi ... ciekawie napisana, dobrze udokumentowaną historię bogatej spuścizny literacko-artystycznej polskiego Londynu przynajmniej ostatnich trzydziestu lat. A tymczasem mamy tylko przedruki” ${ }^{105}$. Publicystka

101 Grzegorz Małkiewicz, „Od Redakcji”, Nowy Czas, nr 8 (206), 2014, 2-3.

102 Jolanta Lane, „Nie wylewajmy dziecka”, 4.

103 „Od Redakcji”, Nowy Czas, nr 11/12 (209-210), 2014, 4.

104 Teresa Bazarnik, „Ojczyzna literatura”, Nowy Czas, nr 3 (201), 2014, 19.

105 Ibidem. 
nie oszczędziła także ambasadora RP Witolda Sobkowa, któremu zarzuciła, że ambasada przestała być salonem dla elity kulturalnej polskiego Londynu.

Przez kilka lat Regina Wasiak-Taylor nie zamierzała reagować na rozpętaną przez Alinę Siomkajło i Redakcję „Nowego Czasu” nagonkę przeciw niej. Nie tłumaczyła się w mediach ze stawianych jej zarzutów, dalej działając społecznie, poświęcając wiele swojego czasu na rzecz polskiej diaspory w Wielkiej Brytanii i poza jej granicami. „Wydawało się jej rzecza niestosowna dowodzić spraw oczywistych" ${ }^{106}$. Jednak próba odebrania jej dobrego imienia, mająca miejsce od 2010 r., i eskalacja rozmaitych działań podjętych przez jej adwersarzy zmusiły ja - także za namowa przyjaciół i rodziny do opublikowania 15 grudnia 2014 r. Listu otwartego na stronie ZPPnO: www.zppno.org., a także do opisania zaistniałej sytuacji w „Pamiętniku Literackim”107. Redakcja „Nowego Czasu”, która według zasad rzetelnego dziennikarstwa - powinna dać możliwość wypowiedzenia się zainteresowanej na swoich łamach, nie zgodziła się na jego zamieszczenie w miesięczniku. Skrót tego listu odnajdujemy w „Indeksie - Piśmie Uniwersytetu Opolskiego” w podwójnym numerze 1-2 z 2015 r. Miejsce o tyle zasadne, że źródła kłopotów autorki publikacji Ojczyzna literatura odnajdujemy właśnie tam. W 2009 r. opolski historyk dr Zbigniew Bereszyński w zasobach Instytutu Pamięci Narodowej odnalazł teczkę z nazwiskiem Reginy Wasiak. Kilka miesięcy później opracowane materiały ogłosił w „Kurierze Brzeskim” pod tytułem „Esbecki cień we władzach Związku Pisarzy Polskich na Obczyźnie"108. Regina Wasiak-Taylor swa teczkę obejrzała po roku od tego wydarzenia. Jak twierdzi:

Nie była obszerna, zawierała prawie wyłącznie raporty sporządzone przez por. Jana Smolińskiego, moje dane osobowe i kilka donosów na mnie. Świadków mojej niewinności nie szukałam, ale przechowuję w swoich zbiorach list Jana Smolińskiego, w którym przeprosił mnie „za wyrzadzone przykrości”. W typowy dla funkcjonariuszy bezpieki sposób wyjaśnia on cele inwigilacji przez SB, którym było nadrzędne „dobro narodu”, usprawiedliwia własne postępowanie

\footnotetext{
106 Wpis dostępny na stronie internetowej [online] [dostęp: 20.12.2015]. Dostępny w World Wide Web: <http://www.zppno.org.listotwartyrwt>.

107 Regina Wasiak-Taylor, „Moja teczka”, PL, t. 48, 2014, 148-154.

108 Z. Bereszyński, „Esbecki cień we władzach Zwiazku Pisarzy Polskich na Obczyźnie”, K:B nr 28 (758), 2009, 7, 10-11.
} 
w stosunku do mnie, kiedy zbierał i spisywał informacje samowolnie „poza wiedzą zainteresowanego, bez pytania o zgodę"109.

Historyk, zgodnie $z$ przeprowadzona kwerenda, przyznał jednak, że nie zachowały się żadne dokumenty poświadczające nawiąanie bezpośredniej współpracy z SB oraz że wszystkie dokumenty $z$ teczki KO „RW”/ „Kasia” zostały wytworzone przez samych funkcjonariuszy SB. Nie ma zatem pewności co do tego, jak naprawdę wyglądały relacje między młoda dziennikarka a SB. R. Wasiak-Taylor w pełnym Liście otwartym w postscriptum napisała, że po tej publikacji otrzymała od opolskiego lustratora list $z$ informacja na temat weryfikacji opolskich dziennikarzy w stanie wojennym, w którym czytamy m.in.:

była Pani jedna $z$ dwóch osób, które postanowiono zwolnić $z$ pracy w opolskiej rozgłośni Polskiego Radia. Decyzję podjęła komisja weryfikacyjna $z$ udziałem znanego Pani funkcjonariusza SB, por. Jana Smolińskiego oraz jego przełożonego, mjr. Józefa Gawrysiaka, naczelnika Wydziału II KW MO. W uzasadnieniu decyzji pisano, że jest Pani „pracownica niezdyscyplinowana i miała powiązania $z$ „Solidarnościa”"110.

Wyjaśnienia wymaga fakt, że jak podaje Wasiak-Taylor, por. Jana Smolińskiego spotykała wielokrotnie w Opolskiej Rozgłośni Polskiego Radia, gdzie rozmawiał $z$ pracownikami na dziedzińcu, w studiu czy radiowej taśmotece. I dalej:

Wykazywał duże zainteresowanie sprawami radia, imponował znajomościa spraw technicznych emisji programów. Był osobą znana mi wcześniej; poznałam go bowiem w katedrze folklorystyki WSP jako męża mgr Teresy Smolińskiej. To właśnie ta pani magister (dzisiaj profesor o liczacym się dorobku naukowym) przedstawiła nam swojego męża jako pracownika działu gospodarczego ... w Komendzie Wojewódzkiej Milicji Obywatelskiej. A on filuternie żartował $\mathrm{z}$ młodymi studentkami, że ma „chody w paszportach i może służyć pomocą!"111.

Ze słów Reginy Wasiak-Taylor wynika, że kontakty z funkcjonariuszem SB były przypadkowe (a nie aranżowane, jak podawał

\footnotetext{
109 Regina Wasiak-Taylor, „Moja teczka”, Indeks, nr 1-2, 2015, 100.

110 Eadem, „List otwarty” [online]. [dostęp: 3.08.2021]. Dostępny w World Wide Web: http:// www.zppno.org/aktualnosci/wasiak-tylor-regina/. 111 Ibidem.
} 
w swoich raportach), ale że widywała go często, ponieważ obie instytucje (radio i KW MO) ze soba sąsiadowały. Wyraźnie podkreśla, że czuje się ofiara polityki i historii oraz że nigdy „nie była tajnym, jawnym, jakimkolwiek innym współpracownikiem służb specjalnych w PRL, nie należała do PZPR, nie podpisała żadnego dokumentu nt. współpracy, nie brała pieniędzy od bezpieki, nie była świadomym informatorem SB, nie donosiła na nikogo"112. Regina Wasiak-Taylor przyznaje, że dopiero po latach okazało się, jaką faktyczna rolę w opolskim radiu pełnił Jan Smoliński, w tym:

Pisał na mnie donosy, albowiem nie można inaczej nazwać streszczeń zasłyszanych rozmów, których był świadkiem, a czasami uczestnikiem. Zapisywał je i umieszczał w swoich służbowych raportach tak, jak bym była na jego usługach. Relacjonował, dodawał od siebie, przeinaczał, konfabulował, a $z$ tych raportów wynikało, że rozmawiał ze mna w protekcjonalnym tonie: instruował, strofował, doradzał, w jaki sposób mam najlepiej osiagnać wyznaczone przez niego zadania. Potrafił też wymyślić całe spotkanie i nadać mu określony temat ${ }^{113}$.

Kiedy pokazała w Polsce pracownikowi IPN teczkę przywieziona $z$ Londynu, ze szkalującymi ja materiałami wytworzonymi przez jej adwersarzy okazało się, że jest ona trzykrotnie grubsza od tej z IPN-u. „Historyk był zdziwiony. Dlaczego? Bo spośród półtora tuzina dziennikarzy radia opolskiego - a chyba wszyscy maja swoje kartoteki i teczki w IPN - aż pięcioro było tajnymi współpracownikami SB i nikt - podkreślam NIKT - $z$ tej piątki nie doczekał się takiej literatury przedmiotu, jak ja"114.

Na marginesie należy zwrócić uwagę, że w 2. tomie „Ekspresji” z 2011 r., wydawanym przez Stowarzyszenie Pisarzy Polskich za Granica w Londynie znajduje się tekst poświęcony Czesławowi Miłoszowi (w Roku Miłosza!), liczący 12 stron, natomiast obelgi i insynuacje pod adresem R. Wasiak-Taylor oraz członków mającego wieloletnią tradycję Zwiąku Pisarzy Polskich na Obczyźnie zajmuja łącznie w roczniku 39 stron...

Patrzac na omawiane zjawiska $z$ perspektywy krajowej, zdumiewa, jak łatwo i szybko można komuś bezwzględnie zniszczyć ży-

\footnotetext{
112 Regina Wasiak-Taylor, „Moja teczka”, 100.

113 Regina Wasiak-Taylor, „List otwarty”, kopia podarowana autorce, 2; archiwum Jolanty Chwastyk-Kowalczyk.

114 Ibidem, 3.
} 
cie, kierując się rozmaitymi pobudkami. I jak niewinna, zdawać by się mogło, książka może wywołać tak silne, destrukcyjne emocje. A sama funkcjonować w atmosferze skandalu. Cóż, nie pierwszy to i nie ostatni zapewne raz w polskiej zbiorowości poza granicami ojczyzny... Za najlepszy komentarz do zaistniałej sytuacji można uznać felieton byłej redaktor naczelnej londyńskiego „Dziennika Polskiego i Dziennika Żołnierza" Katarzyny Bzowskiej-Budd pt. „Diabelskie kubki”, w którym obnaża działania dr Siomkajło, kryjącej się pod kryptonimem Strasznej Kuzynki, i ich odbiór w niektórych kręgach emigracyjnych ${ }^{115}$. Publicystka zaleca rodakom otaczanie się życzliwymi ludźmi, ponieważ według niej tylko $z$ takimi można zrealizować najambitniejsze plany.

Mniej kontrowersji wzbudziła kolejna publikacja Reginy Wasiak-Taylor pt. Alfabet wspomnien Szymona Zaremby. II Rzeczpospolita, II wojna światowa, emigracja, która dzięki wsparciu finansowemu The Hanna \& Zdzisław Broncel Charitable Trust wiosna 2015 r. ukazała się w Londynie, sygnowana przez Związek Pisarzy Polskich na Obczyźnie ${ }^{116}$. Obiekcje zgłaszał syn Szymona Zaremby, ale Regina Wasiak-Taylor nie pozwoliła sobie odebrać praw autorskich do tej książki. Oddaje ona punkt widzenia na różne zjawiska i ludzi, o których się wypowiedział $\mathrm{w}$ rozmowach $\mathrm{z}$ autorka znany działacz społeczny na emigracji na Wyspach Brytyjskich, odznaczający się niepospolitym charakterem. Jak słusznie zauważył w „Przedmowie” Rafał Habielski, książka „ma charakter opowieści biograficznej, której wartość tworzą koleje życia, doświadczenia i obserwacje poczynione przez autora" (s. 11).

Regina Wasiak-Taylor poprzez wydanie Alfabetu wspomnień Szymona Zaremby uratowała od zapomnienia wyjątkowe zaangażowanie w pracę społeczna postaci niezwykłej, która „we wszystkim co robi, osiaga sukces, umie budować, naprawiać szkody i postępuje przyzwoicie wobec innych" (s. 178). Autorka przyznała, że pomysł formy zaczerpnęła z Alfabetu wspomnień Antoniego Słonimskiego, wydanego w 1975 r. Materiał do ksiażki powstawał od maja 2014 do kwietnia 2015 r. podczas poniedziałkowych rozmów z Szy-

115 Katarzyna Bzowska, „Diabelskie kubki”, Dziennik Polski i Dziennik Żołnierza, 29 grudnia, $2014,5$.

116 Zob. recenzje: Jolanta Chwastyk-Kowalczyk, „(rec.) Regina Wasiak-Taylor, Alfabet wspomnień Szymona Zaremby. II Rzeczpospolita, II wojna światowa, emigracja, Londyn 2015, Związek Pisarzy Polskich na Obczyźnie, ss. 191 [1 nlb.]", Zeszyty Naukowe PUNO. Seria trzecia, z. 4, 2016, 275-280; eadem, „Wspomnienia inaczej”, PL, t. 51, 2016, 175-179. 
monem Zarembą w Polskim Ośrodku Społeczno-Kulturalnym, w jego gabinecie, w redakcji „Dziennika Polskiego i Dziennika Żołnierza" w Londynie. Autorka przyznaje, że często musiała ustępować pola konieczności rozwiązywania przez Zarembę różnych węzłów gordyjskich skłóconych emigracyjnych środowisk. Uzupełnieniem były rozmowy telefoniczne, a także książka napisana przez Szymona Zarembę w języku angielskim pt. Recollection of a Distant Past, wydana w Londynie nakładem autora w 2012 r. Ciekawym dodatkiem w publikacji jest dziewięć ilustracji polskiej artystki Olgi Sienko, właścicielki galerii sztuki w Londynie.

Szymon Zaremba po wojnie został w Wielkiej Brytanii. Po demobilizacji studiował ekonomię i księgowość, pracował w angielskich instytucjach finansowych, wykładał w college'u, w latach 1972-2000 prowadził biuro usług księgowych. Równolegle zajmował się działalnością społeczna na rzecz polskiej diaspory w Zjednoczonym Królestwie. Przez wiele lat pełnił funkcję wiceprezesa Zjednoczenia Polskiego w Wielkiej Brytanii, a także prezesa Polskiego Ośrodka Społeczno-Kulturalnego, Rady Fundacji AK i Polskiej Fundacji Kulturalnej.

Na książkę Alfabet wspomnień Szymona Zaremby składa się 200 haseł osobowych i innych dotyczacych dwudziestolecia międzywojennego, okupacji, emigracji, które nabrały kształtu podczas rozmów przeprowadzonych z Reginą Wasiak-Taylor. Wpisuje się ona w naturalny nurt publikacji wspomnieniowych wielu autorów - zawodowych literatów, publicystów, polityków, dyplomatów, artystów, wojskowych oraz żołnierzy i debiutantów, zaistniałych na rynku wydawniczym polskich tułaczy wojennych ${ }^{117}$. Poprzez su-

117 Wydaje się konieczne przypomnienie najważniejszych autorów tej literatury, do których niewatpliwie należa (według chronologii ukazywania się): Wanda Lubomirska, Karmazynowy reportaż, z przedmową Zygmunta Nowakowskiego, (Londyn: Biblioteka Polska, 1946); Marta Rudzka [Beata Obertyńska], $W$ domu niewoli, (Rzym: BOB, 1946; wyd. 2, pod własnym nazwiskiem: Chicago 1968; wyd. 3: Londyn 1988); Józef Żbik, Pierwszy skok, (Londyn: Polska Agencja Drukarska, 1946); Lucjan Kneblewski, Nie taki Murzyn Czarny, (Edynburg: Składnica Księgarska, 1946); Weronika Hort [Hanka Ordonówna], Tułacze dzieci, (Bejrut: Instytut Literacki, 1948); Józef Bartosik, Wierny okręt, (Londyn: Orbis, 1947; K. Jamar, Śladami gasiennic Pierwszej Pancernej, (Londyn: Światpol, 1947); Stanisław Mayak, Dokad idziemy, (Londyn: Orbis, 1947); Zielony talizman, (Londyn: Orbis, 1947); W służbie dla Ojczyzny. Kobieta żotnierzem 2. Korpusu, (Rzym: Referat Kultury i Prasy, 1947); Jerzy Biały, Wspomnienia i przyszłość. 1941-1947, (Londyn: nakładem autora, 1948); Ludomir Rayski, Słowa prawdy o lotnictwie polskim, (Londyn: The Vistula Press, 1948); Wacław Grubiński, Między młotem a sierpem, (Londyn: ZPPnO, 1948); Tadeusz Nowakowski, Szopa za jaśminami, (Londyn: Światpol, 1948); idem, Obóz wszystkich świętych, (Paryż: Libella, 1957); Anatol 


\section{biektywne widzenie rzeczywistości jej bohatera uzupełnia obraz po- strzegania świata przez polską emigrację XX i XXI w., a także po- kazuje inną odsłonę naszej historii, wcześniej zakłamywaną przez władze komunistyczne PRL-u. \\ Publikacja dzięki zamieszczonemu w niej indeksowi osób ułatwi poruszanie się czytelnikowi po współczesnym polskim Lon-}

Krakowiecki, Ksiażka o Kołymie, (Londyn: Veritas, 1950; wyd. 2, Londyn: Veritas, 1987); Gustaw Herling-Grudziński, A World Apart, tłum. J. Marek [Andrzej Ciołkosz], (Londyn: William Heinemann Ltd., 1951; oryginał polski: Inny świat. Zapiski sowieckie, Londyn: Gryf, 1953; wyd. 2, Paryż: 1965); Samodzielna Brygada Strzelców Karpackich, (Londyn: Związek b. Żołnierzy Samodzielnej Brygady Strzelców Karpackich, 1951); Józef Czapski, The Inhuman Land [Na nieludzkiej ziemi], thum. G. Hopkins, (Londyn: Chatto \& Windus, 1951; idem, Na nieludzkiej ziemi, wyd. 2, (Paryż: Instytut Literacki, 1962); Sławomir Rawicz, The Long Walk, (Londyn: Constables, 1956); Kazimierz Iranek-Osmecki, Drogi cichociemnych, (Londyn: Koło Cichociemnych Spadochroniarzy Armii Krajowej, 1952); Tadeusz Wittlin, Diabet w raju, (Londyn: Gryf Publication, 1952); Łucjan Królikowski, Skradzione dzieciństwo, wyd. 2. uzup., (Buffalo, New York: Father Justin Rosary Hour, 1987); Stanisław Kopański, Wspomnienia wojenne 1939-1946, (Londyn: Veritas, 1961); Władysław Wielhorski, Wspomnienia z przeżyć w niewoli sowieckiej, (Londyn: Orbis, 1965); Józef Garliński, Politycy i żolnierze, (Londyn: Polska Fundacja Kulturalna, 1968); Gustaw Łowczowski, Polak jako żotnierz. Moje wspomnienia ze służby żolnierskiej 1914-1948, (Londyn: nakładem autora, 1968); Witold W. Leitgeber, Dziennik z lat wojny 1939-1945. Od Cöetquidan do „Rubensa”, (Londyn, 1972); Jan Nowak [Jeziorański], Kurier $z$ Warszawy, (Londyn: Orbis, 1978); Wacław Korabiewicz, Gdzie słoń a gdzie Polska?, (Londyn: Orbis, 1980); Bohdan Wroński, Wspomnienia płyna jak okręty, ilustr. Hanna Kutek, (Londyn: Odnowa, 1981); Jerzy Roman Krzyżanowski, Generał: opowieść o Leopoldzie Okulickim, (Londyn: Odnowa, 1980); Maria Krzysztoporska, Ze wspomnień tułaczych, (Londyn: Veritas, 1981); Kazimierz Kaz-Ostaszewicz, Długie drogi Syberii, (Londyn: Oficyna Poetów i Malarzy, 1984, wcześniej drukowana w odc. w kanadyjskim Czasie, wyd. 2 uzup. Londyn: Oficyna Poetów i Malarzy, 1986); Jerzy Lerski Jur, Emisariusz „Jur”, (Londyn: Polska Fundacja Kulturalna, 1984; wyd. 2, Warszawa: Oficyna Wydawnicza Interim Sp. z o.o., 1989); Aleksander Bloom, Moja zimna wojna. Wspomnienia emigracyjne, (Londyn: nakładem Kolegów b. Żołnierzy, ich Rodzin, Przyjaciół i Subskrybentów, 1984); Tymon Terlecki, Szukanie równowagi. Szkice literackie i publicystyczne, (Londyn: Oficyna Poetów i Malarzy, 1985; wyd. 2, Warszawa: Fundacja Oficyna 21, 2019; wyd. 3, tamże, 2020); Stefan Jankowicz, Pieśń o pułku naszym, (Londyn: Oficyna Poetów i Malarzy, 1986); Wacław Sieroszewski, Polacy na Syberii, (Londyn: nakładem Koła Żołnierzy 5. Dywizji Strzelców Polskich na Syberii, 1986); Jerzy Stypułkowski, Droga do wojska, (Londyn: Polska Fundacja Kulturalna, 1986); Stanisław Żurakowski, Listy z Kozielska, (Londyn: Polska Fundacja Kulturalna, 1989); Lew Sapieha, Wojna z wysokości siodła, (Londyn: Polska Fundacja Kulturalna, 1986); Klemens Rudnicki, Na polskim szlaku. Wspomnienia z lat 1939-1947, wyd. 4, (Londyn: Gryf, 1986; wyd. 1, Londyn: Gryf, 1952); Jerzy W. Górski, Głodne stepy, (Londyn: Polska Fundacja Kulturalna, 1989), Władysław Filip Łuczyński, Moje cztery kampanie. Wspomnienia z kampanii wrześniowej, francuskiej, libijskiej i włoskiej, (Londyn: Stowarzyszenie Polskich Kombatantów, 1988); Edward Raczyński, Czas wielkich zmian, (Paryż: Inne, 1990); Tadeusz Walczak, Życie nie tylko własne, (Londyn: Polska Fundacja Kulturalna, 1996); Józef Garliński, Świat mojej pamięci. Wspomnienia, t 1 i 2, (Londyn-Warszawa: Polska Fundacja Kulturalna, 1998); Andrzej Krzeczunowicz, Bołszowce. Wspomnienie z dzieciństwa na Kresach, (Warszawa: Wydawnictwo DiG, 2014); Irena Baczkowska, Letnie noce, (Londyn: Veritas Foundation Publication Centre, 2005); Danuta Waszczukówna-Kamieniecka, Brześć. Niezapomniane miasto, wyd. 4, (Londyn: nakładem autorki, 2018). 
dynie. Na pewno zainteresuje badaczy życia i działalności polskiej diaspory na obczyźnie i to różnych dyscyplin naukowych.

Niestety Szymon Zaremba nie doczekał wydania tej książki drukiem, ponieważ zmarł 22 sierpnia 2015 r. w Londynie.

Zamiast wspólnie omawianej i obmyślonej promocji autorka Alfabetu urządziła swojemu bohaterowi wieczór poświęcony jego pamięci. Na spotkanie w Polskim Ośrodku Społeczno-Kulturalnym przybyli liczni przyjaciele i znajomi Szymona Zaremby, który za swojej prezesury doprowadził ośrodek do rozkwitu. Ale - jak mówi Regina Wasiak-Taylor - ten polski Londyn jest już inny:

Kiedy tutaj przyjechałam na początku lat 80 . XX wieku polski krajobraz pulsował różnorodnościa polskich spraw, były gazety, tygodniki emigracyjne, fundacje, księgarnie, apteki, wydawnictwa, drukarnie, uniwersytet PUNO, który wydawał dyplomy magisterskie, każdego roku ogłaszano kilkanaście nagród literackich... W dzisiejszym polskim Londynie brak wielkich Polaków, takich ważnych osobistości, a przy tym ludzi prawych, mogacych być pewnym wzorem intelektualnym i moralnym dla wielu emigrantów... Pamiętam jeszcze prezydenta Kazimierza Sabbata, Ryszarda Kaczorowskiego, Edwarda Raczyńskiego - na ich komentarze i wystapienia czekali wszyscy. Były też wielkie kobiety: Renata Bogdańska, czyli generałowa Irena Anders, Włada Majewska - charyzmatyczne artystki i kobiety z dużym charakterem. Dzisiaj jest nas w Londynie dużo więcej, ale krajobraz się spłaszczył, zszarzał, nie ma wielkich indywidualności i to mnie niepokoi ${ }^{118}$.

Regina Wasiak-Taylor ma kilka swoich ulubionych tematów. Jest nim przykładowo odkrywanie kultury małych miasteczek, ich siły i odmienności prowadzacych do wykreowania niezwykłych osobowości ważnych i liczących się później w kraju i nierzadko za granica. To temat wciąż niedoceniony. W swoich wystapieniach proponuje świeże spojrzenie na fenomen małego miasteczka, jego znaczenia i wkładu do kultury narodowej. Od kilku lat poświęca więcej uwagi kontaktom $z$ rodzinnym miastem Krapkowice na Śląsku opolskim. Z burmistrzem Krapkowic rozpoczęła cykl spotkań literacko-muzycznych pod tytułem „Z Krapkowic w świat”. Pierwszy odbył się 26 października 2019 r., który zarejestrował krapkowi-

118 Wywiad przeprowadzony przez J. Chwastyk-Kowalczyk z Reginą Wasiak-Taylor w Londynie 10.10.2019 r. 
czanin, Andrzej Wdowik. Dwugodzinny film jest dostępny pod adresem: https://youtube/QUJOoSSVp-k.

Najnowszym jej pomysłem było nagranie w marcu $2021 \mathrm{r}$. 6-odcinkowego cyklu filmów Norwid $w$ Anglii, w którym udokumentowano ślady poety w Londynie. Jest to koprodukcja Zwiazku Pisarzy Polskich na Obczyźnie z Instytutem Kultury Europejskiej Polskiego Uniwersytetu na Obczyźnie powstała z okazji 200. rocznicy urodzin Norwida. Wystapiły w nich Regina Wasiak-Taylor, Krystyna Kaplan i Maja Komorowska. Dwa odcinki pokazano podczas międzykontynentalnej konferencji naukowej pod hasłem: „Cyprian Norwid Yesterday and Today”, zorganizowanej przez PUNO 9-11 kwietnia 2021 r. w Londynie.

Nasza bohaterka została odznaczona medalem Pro Memoria w 2009 r. i Złotym Krzyżem Zasługi w 2010 r.

\section{Bibliografia}

\section{Publikacje zwarte}

Bartosik, Józef. Wierny okręt (Londyn: Orbis, 1947).

Baczkowska, Irena. Letnie noce (Londyn: Veritas Foundation Publication Centre, 2005).

Bertram, Łukasz (wybór i oprac.), Obieg NOW-ej, (Warszawa: Ośrodek Karta i IPN, 2013).

Biały, Jerzy. Wspomnienia i przyszłość. 1941-1947 (Londyn: nakładem autora, 1948).

Bloom, Aleksander. Moja zimna wojna. Wspomnienia emigracyjne (Londyn: nakładem Kolegów b. Żołnierzy, ich Rodzin, Przyjaciół i Subskrybentów, 1984).

Choma-Jusińska, Małgorzata. Środowiska opozycyjne na Lubelszczyźnie. 1975-1980, (Lublin: IPN, 2009).

Chwastyk-Kowalczyk, Jolanta. „Ksiażka, która otworzyła puszkę Pandory w "polskim Londynie" w XXI wieku", w: Teresa Wilkoń (red.), O etosie ksiażki. Studia z dziejów bibliotek i kultury czytelniczej, (Katowice: Wydawnictwo Uniwersytetu Ślaskiego, 2017), 528-539.

Chwastyk-Kowalczyk, Jolanta. Londyński „Dziennik Polski” 19401943, (Kielce: Wydawnictwo Akademii Świętokrzyskiej, 2005).

Chwastyk-Kowalczyk, Jolanta. Londyński „Dziennik Polski i Dziennik Żotnierza" 1944-1989. Gazeta codzienna jako środek przekazu komunikatów kulturowych, (Kielce: Wydawnictwo Uniwer- 
sytetu Humanistyczno-Przyrodniczego Jana Kochanowskiego, 2008).

Chwastyk-Kowalczyk, Jolanta. Londyński „Pamiętnik Literacki” - organ Zwiazku Pisarzy Polskich na Obczyźnie - w latach 1976-2018, (Kielce: Wydawnictwo Uniwersytetu Jana Kochanowskiego, 2019).

Garliński, Józef. Politycy i żołnierze, (Londyn: Polska Fundacja Kulturalna, 1968).

Garliński, Józef. Świat mojej pamięci. Wspomnienia, t. 1 i 2, (Londyn-Warszawa: Polska Fundacja Kulturalna, 1998).

Górski, Jerzy W., Głodne stepy, (Londyn: Polska Fundacja Kulturalna, 1989).

Grubiński, Wacław. Między młotem a sierpem, (Londyn: ZPPnO, 1948).

Herling-Grudziński, Gustaw. A World Apart, tłum. J. Marek [Andrzej Ciołkosz], (Londyn: William Heinemann Ltd., 1951; oryginał polski: Inny świat. Zapiski sowieckie, wyd. 1, Londyn: Gryf, 1953; wyd. 2, Paryż: 1965).

Hort, Weronika [Hanka Ordonówna]. Tułacze dzieci, (Bejrut: Instytut Literacki, 1948).

Iranek-Osmecki, Kazimierz. Drogi cichociemnych, (Londyn: Koło Cichociemnych Spadochroniarzy Armii Krajowej, 1952).

Jamar, K. Śladami gassiennic Pierwszej Pancernej, (Londyn: Światpol, 1947).

Jankowicz, Stefan. Pieśń o pułku naszym, (Londyn: Oficyna Poetów i Malarzy, 1986).

Kaz-Ostaszewicz, Kazimierz. Długie drogi Syberii, (Londyn: Oficyna Poetów i Malarzy, 1984; wcześniej drukowana w odc. w kanadyjskim „Czasie”, wyd. 2 uzup., Londyn: Oficyna Poetów i Malarzy, 1986).

Kłossowski, Andrzej. Na obczyźnie. Ludzie polskiej książki, (Wrocław: Zakład Narodowy im. Ossolińskich, 1984).

Kopański, Stanisław. Wspomnienia wojenne 1939-1946, (Londyn: Veritas, 1961).

Korabiewicz, Wacław. Gdzie słon a gdzie Polska?, (Londyn: Orbis, 1980).

Krakowiecki, Anatol. Ksiażka o Kołymie, (Londyn: Veritas, 1950; wyd. 2, Londyn: Veritas, 1987).

Królikowski, Łucjan. Skradzione dzieciństwo, wyd. 2. uzup., (Buffalo-New York: Father Justin Rosary Hour, 1987). 
Krzeczunowicz, Andrzej. Bołszowce. Wspomnienie z dzieciństwa na Kresach, (Warszawa: Wydawnictwo DiG, 2014).

Krzysztoporska, Maria. Ze wspomnien tułaczych, (Londyn: Veritas, 1981).

Krzyżanowski, Jerzy Roman. Generat: opowieść o Leopoldzie Okulickim, (Londyn: Odnowa, 1980).

Leitgeber, Witold W. Dziennik z lat wojny 1939-1945. Od Cöetquidan do „Rubensa”, (Londyn, 1972).

Lerski, Jerzy Jur. Emisariusz „Jur”, (Londyn: Polska Fundacja Kulturalna, 1984; wyd. 2, Warszawa: Oficyna Wydawnicza Interim Sp. z o.o., 1989).

Lubomirska, Wanda. Karmazynowy reportaż (z przedmową Zygmunta Nowakowskiego, (Londyn: Biblioteka Polska, 1946).

Łowczowski, Gustaw. Polakjako żołnierz. Moje wspomnienia ze służby żolnierskiej 1914-1948, (Londyn: nakładem autora, 1968).

Łuczyński, Filip. Moje cztery kampanie. Wspomnienia z kampanii wrześniowej, francuskiej, libijskiej i włoskiej, (Londyn: Stowarzyszenie Polskich Kombatantów, 1988).

Mayak, Stanisław. Dokąd idziemy, (Londyn: Orbis, 1947).

Nowak, Jan [Jeziorański]. Kurier z Warszawy, (Londyn: Orbis, 1978).

Nowakowski, Tadeusz. Obóz wszystkich świętych, (Paryż: Libella, 1957).

Nowakowski, Tadeusz. Szopa za jaśminami, (Londyn: Światpol, 1948).

Pytasz, Ewa. Pytasz, Marek. „Bednarczykowie jako wydawcy (rekonesans)", w: Tadeusz Bujnicki, Wojciech Wyskiel (red.), Pisarz na obczyźnie, (Wrocław: Zakład Narodowy im. Ossolińskich, 1985).

Raczyński, Edward. Czas wielkich zmian, (Paryż: Inne, 1990).

Rawicz, Sławomir. The Long Walk, (Londyn: Constables, 1956).

Rayski, Ludomir. Słowa prawdy o lotnictwie polskim, (Londyn: The Vistula Press, 1948).

Rudnicki, Klemens. Na polskim szlaku. Wspomnienia z lat 1939 1947, wyd. 4, (Londyn: Gryf, 1986; wyd. 1, Londyn: Gryf, 1952). Rudzka, Marta [Beata Obertyńska]. W domu niewoli, (Rzym: BOB, 1946; wyd. 2 pod własnym nazwiskiem, Chicago: 1968, wyd. 3, Londyn: 1988).

Samodzielna Brygada Strzelców Karpackich, (Londyn: Związek b. Żołnierzy Samodzielnej Brygady Strzelców Karpackich, 1951). 
Sapieha, Lew. Wojna z wysokości siodła, (Londyn: Polska Fundacja Kulturalna, 1986).

Sieroszewski, Wacław. Polacy na Syberii, (Londyn: nakładem Koła Żołnierzy 5. Dywizji Strzelców Polskich na Syberii, 1986).

Stypułkowski, Jerzy. Droga do wojska, (Londyn: Polska Fundacja Kulturalna, 1986).

Terlecki, Tymon. Szukanie równowagi. Szkice literackie i publicystyczne, (Londyn: Oficyna Poetów i Malarzy, 1985; wyd. 2, Warszawa: Fundacja Oficyna 21, 2019; wyd. 3, tamże, 2020).

W służbie dla Ojczyzny. Kobieta żotnierzem 2. Korpusu, (Rzym: Referat Kultury i Prasy, 1947).

Walczak, Tadeusz. Życie nie tylko własne, (Londyn: Polska Fundacja Kulturalna, 1996).

Wasiak-Taylor, Regina. Ojczyzna literatura. O środowisku skupionym wokół Zwiazku Pisarzy na Obczyźnie, (Londyn: Oficyna Poetów i Malarzy, 2013).

Waszczukówna-Kamieniecka, Danuta. Brześć. Niezapomniane miasto, wyd. 4, (Londyn: nakładem autorki, 2018).

Wielhorski, Władysław. Wspomnienia $z$ przeżyć $w$ niewoli sowieckiej, (Londyn: Orbis, 1965).

Wittlin, Tadeusz. Diabeł $w$ raju, (Londyn: Gryf Publication, 1952).

Wroński, Bohdan. Wspomnienia płyna jak okręty, ilustr. Hanna Kutek, (Londyn: Odnowa, 1981).

Zielony talizman, (Londyn: Orbis, 1947).

Żbik, Józef. Pierwszy skok, (Londyn: Polska Agencja Drukarska, 1946).

Żurakowski, Stanisław. Listy z Kozielska, (Londyn: Polska Fundacja Kulturalna, 1989).

\section{Artykuły naukowe}

„Biblioteki polskie poza krajem”, Pamiętnik Literacki, t. 10, 1986, 55-58.

Chwastyk-Kowalczyk, Jolanta. „Oficyna Poetów“ - niszowy kwartalnik literacko-artystyczny (1966-1980)", Rocznik Historii Prasy Polskiej, t. 16, z. 2 (3), 2013, 117-132.

Chwastyk-Kowalczyk, Jolanta (rec.), „Regina Wasiak-Taylor. Alfabet wspomnien Szymona Zaremby. II Rzeczpospolita, II wojna światowa, emigracja, Londyn 2015, Zwiazek Pisarzy Polskich na Obczyźnie, ss.191 [1 nlb.]", Zeszyty Naukowe PUNO 2016, seria trzecia, z. 4, 275-280. 
Chwastyk-Kowalczyk, Jolanta (rec.), „Regina Wasiak-Taylor. Ojczyzna literatura. O środowisku skupionym wokół Związku Pisarzy na Obczyźnie, Oficyna Poetów i Malarzy, Londyn 2013, 285 ss., 3 nlb.", Zeszyty Naukowe PUNO, nr 2, 2014, 283-286.

Chwastyk-Kowalczyk, Jolanta (rec.), „Regina Wasiak-Taylor. Ojczyzna literatura. O środowisku skupionym wokół Związku Pisarzy Polskich na Obczyźnie, Londyn 2013, Oficyna Poetów i Malarzy, ss. 288, ISBN: 978-0-9570372-1-2", Rocznik Bibliologiczno-Prasoznawczy, nr 6/17, 2014, 315-318.

Chwastyk-Kowalczyk, Jolanta. „Wspomnienia inaczej”, Pamiętnik Literacki, t. 51, 2016, 175-179.

Czapski, Józef. The Inhuman Land [Na nieludzkiej ziemi], tłum. G. Hopkins, (Londyn: Chatto \& Windus, 1951; wyd. 2: Na nieludzkiej ziemi, Paryż: Instytut Literacki, 1962).

Dorosz, Beata. „Zapomniani pisarze emigracyjni”, Pamiętnik Literacki, t. 57, 2019, 36.

Garliński, Józef. „Czy pożegnanie?”, Pamiętnik Literacki, t. 24, 1999, 110.

Garliński, Józef. „Pożegnanie”, Pamiętnik Literacki, t. 28, 2003, 7. „Historia Oficyny. Krystyna Bednarczyk, Czesław Bednarczyk. Rozmowę przeprowadził M. Pytasz", Fraza, nr 1-2, 1998, 112-118.

Kneblewski, Lucjan. Nie taki Murzyn Czarny, (Edynburg: Składnica Księgarska, 1946).

Maxwell, Grażyna. „Zwiazek Pisarzy w delegacji”, Pamiętnik Literacki, t. 57, 2019, 283-286.

Miązek, Bonifacy. „Ksiażka ważna i potrzebna”, Pamiętnik Literacki, t. 47, 2013, 162-170.

Tatarowski, Konrad W., „Ostatni rozdział literatury emigracyjnej Irena Baczkowska", Acta Universitatis Lodziensis. Folia Litteraria Polonica, z. 10, 2008, 167-171.

Wasiak, Regina, „Biblioteka Polska w Londynie”, Pamiętnik Literac$k i$, t. $12,1988,66-81$.

Wasiak, Regina. "Głosy o "Kulturze", Pamiętnik Literacki, t. 11, 1987, 35-38.

Wasiak, Regina. „Literatura emigracyjna w drugim obiegu. Wywiad z Magdalena Abe", Pamiętnik Literacki, t. 13, 1988, 66-72.

Wasiak, Regina. „Na marginesie krajowych opracowan literatury polskiej na obczyźnie”, Pamiętnik Literacki, t. 7, 1984, 75-86.

Wasiak, Regina. „Nasi laureaci”, Pamiętnik Literacki, t. 7, 1983, 79-91. 
Wasiak-Taylor, Regina. „Nasi laureaci: Jerzy R. Krzyżanowski, Ludwika Amber", Pamiętnik Literacki, t. 22, 1997, 80-81.

Wasiak, Regina. „Nasi laureaci. Kilka myśli o Mrożku”, Pamiętnik Literacki, t. 8, 1984, 110-114.

Wasiak, Regina. „Nasi laureaci. Nie tylko dla dorosłych”, Pamiętnik Literacki, t. 10, 1986, 70-74.

Wasiak-Taylor, Regina. „Nasi laureaci: Ryszard Kazimierz Lewański, Andrzej Nils Uggla”, Pamiętnik Literacki, t. 21, 1996, 104-106.

Wasiak, Regina. „Nie ma ucieczki od Soplicowa”, Pamiętnik Literacki, t. 9, 1985, 106-111.

Wasiak, Regina. „Polska na rozdrożu (Autoryzowana rozmowa $z$ Janem Józefem Lipskim)", Pamiętnik Literacki, t. 14, 1989, 138-141.

Wasiak, Regina. „Polszczyzna jest moja obsesja”, Pamiętnik Literac$k i$, t. 9, 1985, 101-106.

Wasiak-Taylor, Regina, „24 lata w roli redaktora i wydawcy”, $\mathrm{Pa}$ miętnik Literacki, t. 24, 1999,103-109.

Wasiak-Taylor, Regina, „Alfabet wspomnień Szymona Zaremby”, Pamiętnik Literacki, t. 49, 2015, 143-153.

Wasiak-Taylor, Regina. „Archiwum Oficyny Poetów i Malarzy opuszcza Londyn", Pamiętnik Literacki, t. 43/44, 2012, 59-72.

Wasiak-Taylor, Regina. „Archiwum Oficyny Poetów i Malarzy opuszcza Londyn cd.", Pamiętnik Literacki, t. 45/46, 2013, 83-93.

Wasiak-Taylor, Regina. „Był dom”, Pamiętnik Literacki, t. 34, 2007, 93-100.

Wasiak-Taylor Regina. „Doktor honoris causa Polskiego Uniwersytetu na Obczyźnie dla Krystyny Bednarczyk - poetki, drukarza i wydawcy", Pamiętnik Literacki, t. 36, 2008, 9-15.

Wasiak-Taylor, Regina. „Drugie półwiecze Oficyny Poetów i Malarzy", Pamiętnik Literacki, t. 30, 2005, 49-55.

Wasiak-Taylor, Regina. „Dwukrotny sukces Aleksandry Ziółkowskiej-Boehm - książka i nagroda", Pamiętnik Literacki, t. 35, 2008, 65-66.

Wasiak-Taylor, Regina. „Historie prawdziwe”, Pamiętnik Literacki, t. 52, 2016, 206-211.

Wasiak-Taylor, Regina. „Kazimierz Sowiński - pisarz, inicjator pisma Zwiazku Pisarzy Polskich na Obczyźnie", Zeszyty Naukowe PUNO, nr 4, 2016, 183-194.

Wasiak-Taylor Regina, „Książka w herbie Jerzego Kulczyckiego”, Pamiętnik Literacki, t. 40, 2010, 67-82. 
Wasiak-Taylor, Regina. „Laureaci nagród literackich ZPPnO”, $\mathrm{Pa}$ miętnik Literacki, t. 42, 2011, 49-61.

Wasiak-Taylor, Regina. „Na tropach Aleksandry Ziółkowskiej-Boehm", Pamiętnik Literacki, t. 35, 2008, 67-81.

Wasiak-Taylor, Regina. „Narcyza and Ursula”, Pamiętnik Literacki, t. 56, 2018, 101-106.

Wasiak-Taylor, Regina. „Nasi laureaci: Jerzy R. Krzyżanowski, Ludwika Amber", Pamiętnik Literacki, t. 22, 1997, 80-81.

Wasiak-Taylor, Regina. „Niezwykła kariera "Czerwonych maków", Pamiętnik Literacki, t. 29, 2004, 89-93.

Wasiak-Taylor, Regina. „O balecie sprzed 150 lat”, Pamiętnik Literacki, t. 43/44, 2012, 186-189.

Wasiak-Taylor, Regina. „O krytyce i krytykach teatru emigracyjnego w Londynie", Pamiętnik Literacki, t. 27, 2002, 63-80.

Wasiak-Taylor, Regina. „Od poezji serdecznych po haiku Bolesława Kobrzyńskiego", Pamiętnik Literacki, t. 57, 2019, 93-105.

Wasiak-Taylor, Regina. „Ostatnia niezwykła kresowianka”, Pamiętnik Literacki, t. 31, 2006, 83-92.

Wasiak-Taylor, Regina. „Pisarze emigracyjni tworzacy dla scen ZASP-u za granica”, Pamiętnik Literacki, t. 25, 2000, 50-72.

Wasiak-Taylor, Regina. „Podleska w 17. Salonie Literackim”, $\mathrm{Pa}$ miętnik Literacki, t. 54, 2017, 209-219.

Wasiak-Taylor, Regina. „Polski Uniwersytet na Obczyźnie - wydarzenia o charakterze literackim w 2014 roku", Pamiętnik Literacki, t. 48, 2014, 143-150.

Wasiak-Taylor, Regina. „Siostra Bożena i sor Juana Inés de la Cruz", Pamiętnik Literacki, t. 53, 2017, 115-124.

Wasiak-Taylor, Regina. „Szekspir, Maria i Magdalena”, Pamiętnik Literacki, t. 52, 2016, 59-68.

Wasiak-Taylor, Regina. „Wieczór poezji Mieczysława Paszkiewicza”, Pamiętnik Literacki, t. 28, 2003, 111-115.

Wasiak-Taylor, Regina. „Wit Tarnawski i Conrad”, Pamiętnik Literacki, t. 55, 2018, 71-78.

Wasiak-Taylor, Regina. „Zaszczyt wielki, korzyść mniejsza”, Pamiętnik Literacki, t. 42, 2011, 19-25.

\section{Artykuly prasowe}

Bazarnik, Teresa. „Ojczyzna literatura”, Nowy Czas, nr 3 (201), 2014, 19. 
Bednarczyk, Krystyna. „Między Kultura a Wiadomościami. Rozmowę przeprowadził J. Kryszak", Kwartalnik Artystyczny, nr 3, 1996, 70-75.

Bereszyński, Zbigniew. Esbecki cień we władzach Zwiazku Pisarzy Polskich na Obczyźnie, „Kurier Brzeski”, nr 28 (758), 2009, 7, 10-11.

„Brzękowski i "Oficyna Poetów"”, Twórczość, nr 4, 1968, 142-144.

Bzowska, Katarzyna. „Diabelskie kubki”, Dziennik Polski i Dziennik Żotnierza, 29 grudnia, 2014, 5.

Gulbicki, Piotr. „W poszukiwaniu dawnych wielkości”, Dziennik Polski i Dziennik Żolnierza, nr 77, 2014, dodatek Tydzień Polski, nr 16, 2014, 8.

Hartwig, Julia. „Drukarnia pod mostem”, Więź, nr 2, 2004, 137-140. Kaliszewski, Wojciech. „Ostatnie”, Nowe Ksiażki, nr 8, 2014, 64-65. Kochańczyk, Adam. „Piękne książki Bednarczyków”, Akcent, nr 1-2, 2004, 273-275.

Koźmiński, Józef. „Oficyna Poetów“ i malarze”, Kwartalnik Artystyczny, nr 3, 1996, 76-82.

„Kronika Zwiąku”, Pamiętnik Literacki, t. 10, 1986,103.

„Kronika Związku”, Pamiętnik Literacki, t. 34, 2007, 150.

„Kronika Związku”, Pamiętnik Literacki, t. 36, 2008, 156.

„Kronika Związku”, Pamiętnik Literacki, t. 37, 2009, 148.

„Kronika Związu”, Pamiętnik Literacki, t. 39, 2010, 150.

„Kronika Związku”, Pamiętnik Literacki, t. 43/44, 2012, 203-205

„Kronika Zwiazku”, Pamiętnik Literacki, t. 45/46, 2013, 204.

„Kronika Związu”, Pamiętnik Literacki, t. 49, 2015, 177-178.

„Kronika Zwiazku”, Pamiętnik Literacki, t. 52, 2016, 221.

„Kronika Związku”, Pamiętnik Literacki, t. 56, 2018, 237-238.

„Kronika Zwiąku”, Pamiętnik Literacki, t. 57, 2019, 277.

Krzyżanowski, Jerzy. „Ojczyzna literatura”, Przegląd Polski- dodatek kulturalny do nowojorskiego Nowego Dziennika, kwiecień, 2014, 9. „Ksiaż̇ka cenna i rzadka”, Nasza Polska, nr 26, 2014, 9.

Lane, Jolanta. „Nie wylewajmy dziecka $z$ kapiela”, Nowy Czas, nr 11/12 (209-210), 2014, 3-4.

Legeżyński, Stefan. „15 lat Oficyny Poetów i Malarzy”, Wiadomości, nr 968, 1964, 4.

Małkiewicz, Grzegorz. „Od Redakcji”, Nowy Czas, nr 8 (206), 2014, 2-3.

Masłoń, Krzysztof. „Emigracyjny przypadek”, Do Rzeczy, $\mathrm{nr} 28$, 2014, 47. 
Miązek, Bonifacy. „O naszym środowisku”, Nowy Czas, nr 8 (206), 2014, 2.

„Nie zmarnowany czas. Krystyna Bednarczykowa. Rozmowę przeprowadzili K. Dorosz, P. Tański”, Przegląd Powszechny, nr 2, 2003, 172-180.

"Od Redakcji”, Nowy Czas, nr 11/12 (209-210), 2014, 4.

„Opium. Z Krystyną i Czesławem Bednarczykami, założycielami i właścicielami Oficyny Poetów i Malarzy rozmawia A. Ziembicki”, Nowe Ksiażki, nr 10, 1981, 1-6.

Orski, Mieczysław. „Londyńska Ojczyzna literatury”, Odra, nr 2, 2014, 131-132

Sambor, Michał. „Oficyna Poetów i Malarzy”, Kultura, nr 4, 1953, 127-130.

Siomkajło, Alina. „Poproszę o receptę”, Nowy Czas, nr 11/12 (209210), 2014, 3.

Siomkajło, Alina. „Przygoda wydawnicza. Tylko dla żądnych świadomości”, Nowy Czas, nr 7 (205), 2014, 20.

Wasiak-Taylor, Regina. „Dla przyjaciół za wierność”, Pamiętnik Literacki, t. 47, 2014, 147-151.

Wasiak-Taylor, Regina. „Moja teczka”, Indeks, nr 1-2, 2015,100.

Wasiak-Taylor, Regina. „Moja teczka”, Pamiętnik Literacki, t. 48, 2014, 148-154.

Wasiak-Taylor, Regina. „Od redakcji”, Pamiętnik Literacki, t. 58, 2019, 7.

Wasiak-Taylor, Regina. „Wspomnienie o Zbigniewie Makowieckim 1917-2017", Pamiętnik Literacki, t. 54, 2017, 269-271.

Wasiak-Taylor, Regina. „Żegnaj, drogi Przyjacielu!”, Pamiętnik Literacki, t. 38, 2009, 151-152.

Waśkiewicz, Andrzej Krzysztof. „Oficyna Poetów“ czyli o mecenacie”, Życie Literackie, nr 15 (1159), 1974, 4.

„Wpłaty na Fundusz Prasowy "Pamiętnika Literackiego" oraz Związek Pisarzy Polskich na Obczyźnie”, PL, t. 57, 2019, 4.

"Wyniki apelu na Fundusz Prasowy "Pamiętnika Literackiego" ogłoszony przez Zarząd Związku Pisarzy Polskich na Obczyźnie", $\mathrm{Pa}$ miętnik Literacki, t. 27, 2002, 117.

\section{Inne}

E-mail Reginy Wasiak-Taylor do Jolanty Chwastyk-Kowalczyk, 5.01.2020, archiwum Jolanty Chwastyk-Kowalczyk. 
E-mail Reginy Wasiak-Taylor do Jolanty Chwastyk-Kowalczyk, 29.01. 2020, archiwum Jolanty Chwastyk-Kowalczyk.

Wasiak-Taylor Regina, List otwarty, kopia podarowana autorce, 1-3; archiwum Jolanty Chwastyk-Kowalczyk.

Wywiad przeprowadzony przez J. Chwastyk-Kowalczyk z Regina Wasiak-Taylor w Londynie 10.10.2019, archiwum Jolanty Chwastyk-Kowalczyk.

\section{Netografia}

Konikiewicz, Andrzej. „Podwójne epitafium”, Rzeczpospolita, 15.04. 2014 [online] [dostęp: 14.09.2015]. Dostępny w World Wide Web: <http:/ / www.rp.pl/artykul/9148,1102083-Podwojne-epitafium.html>.

Wpis dostępny na blogu [online] [dostęp: 14.09.2015]. Dostępny w World Wide Web: <http: / www.taylor.blogspot.com/2014/05/ gosy-o-ksiazce-mieczysaw-orski.html>.

Wpis dostępny na stronie internetowej [online] [dostęp: 12.09.2015]. Dostępny w World Wide Web: <http://www.alinasiomkajło.iap. $\mathrm{pl} / \mathrm{pl}>$.

Wpis dostępny na stronie internetowej [online] [dostęp: 20.12.2015]. Dostępny w World Wide Web: <http://www.zppno.org.listotwartyrwt>. 